Article

\title{
Technogenic Magnetic Particles in Soils and Ecological-Geochemical Assessment of the Soil Cover of an Industrial City in the Ural, Russia
}

\author{
Andrei Vasiliev*(D), Svetlana Gorokhova ${ }^{(D)}$ and Mikhail Razinsky \\ Soil Science Department, Federal State Budgetary Educational Institution of Higher Education, \\ Perm State Agro-Technological University, st. Petropavlovskaya, Building 23, 614990 Perm, Russia; \\ gorohova.s@hotmail.com (S.G.); pochva@pgsha.ru (M.R.) \\ * Correspondence: a.a.vasilev@list.ru; Tel.: +7-(342)-217-94-39
}

Received: 26 October 2020; Accepted: 4 November 2020; Published: 6 November 2020

check for updates

\begin{abstract}
The work is devoted to the study of pollution by technogenic magnetic particles and heavy metals of soils in the city of Gubakha, Middle Ural (Russia). The aim of the work is the ecological and geochemical assessment of the elemental chemical composition of the soils of the city of Gubakha, and the establishment of the geochemical role of technogenic magnetic particles (TMPs). For the first time, the regularities of the spatial distribution of magnetic susceptibility in the soils of the city of Gubakha were revealed, and the morphology, elemental and mineralogical compositions of magnetic particles in the soils of an industrial city in the Middle Urals were characterized using the methods of the chemical extraction of iron compounds, magnetic separation, ESEM/EDS, and Mössbauer spectroscopy. The magnetic phase of soils contains magnetite/maghemite, hematite, pyrrhotite, intermetallic alloys and chromite. Spherical magnetic particles are hollow, and have a magnetite shell and a varied surface texture. The crystal lattice of magnetite is characterized by low stoichiometry. The heavy metals $\mathrm{Zn}, \mathrm{Cu}, \mathrm{Ni}$ and $\mathrm{Cr}$ are concentrated in magnetic particles and have a high correlation coefficient with magnetic susceptibility. The level of contamination of $\mathrm{Cu}, \mathrm{Ni}, \mathrm{Zn}, \mathrm{Cr}$ and $\mathrm{Mn}$ in the soils of a residential zone of Gubakha, estimated by the value of the pollution load index (PLI), was high. The Igeo index for Fe ranges from 6.2 to 12.2, for $\mathrm{Cu}-1.1$ and Ni-1.1. The combination of methods for measuring magnetic susceptibility, determining the mineralogical composition of iron compounds, and determining the elemental chemical composition by $\mathrm{X}$-ray fluorescence, has shown the effectiveness of an integrated approach for carrying out an ecological-geochemical assessment of the soil cover of Gubakha.
\end{abstract}

Keywords: soil; iron; heavy metals; magnetic susceptibility; technogenic magnetic particles; magnetite spherules; Ural

\section{Introduction}

One of the main scientific approaches to solving the problem of soil pollution with heavy metals $(\mathrm{HM})$ is the ecological-geochemical analysis of quantitative and qualitative indicators of the elemental chemical composition of soils, and the identification of pollution sources and carrier phases of heavy metals.

HM pollution of the soil cover of urbanized areas occurs as a result of the impact of industrial enterprises (Ni [1-8], Cu [1,2,4,5,9-15], Zn [1,5,8,9,11-20], Mn [1-3,9,18,21], Cr [9,11,18,22-25] etc.), fossil fuel combustion products ( $\mathrm{Ni}[3,11,21,26-28], \mathrm{Mn}[3,21,27,29,30], \mathrm{Zn}[10,26,28,31], \mathrm{Cu}[10,11,19,26,31]$, $\mathrm{Cr}[26,28,30-32]$ and $\mathrm{Zn}[27,32])$ and road-traffic pollution ( $\mathrm{Cu}[6,9,11,12,16,18,21,23,25,33-44]$, Zn $[6,10,11,16,23,25,33-37,39,41-47]$, Cr $[9,11,21,34,37,40,44,46]$, Mn $[9,43,45]$ and Ni $[37,40,44,45])$. 
It has been established that in urban soils, the phases-carriers of heavy metals are organic matter, clay minerals [48], as well as natural iron (hydr)oxides (goethite [49], lepidocrocite [50]), and technogenic magnetic particles (TMPs) (magnetite [49-59], maghemite [49,50,52,55,59], magnesioferrite [49,52], hematite [49,50,52,53,55,57], pyrrhotite [49], ferrites [49,52], wustite [55], metallic iron [53,60], ferroalloy [60]). Anthropogenic pollution of soils with HM occurs in the composition of TMPs from fly ash of power plants [26,28], exhaust gases, the wear of tires, brakes and road surfaces, the corrosion of car bodies, oil leakage [42], and dust from wheels and the rails of the railway transport [39].

In areas with a developed industrial infrastructure for coal processing and thermal power enterprises using coal, there is a connection between HM and the magnetic phase of fly ash from coal-fired power plants [49,61-64]. In magnetic concentrates of coal dust, the dominant magnetic phase is $50 \%$ magnetite with a predominance of spherical particles $[49,65]$.

Based on the relationship between iron compounds and the ecological state of the soil cover, the methods of ecological magnetism are used in soil cover monitoring for magnetic susceptibility $(K)$, remanent magnetization, saturation magnetization, coercive force, thermomagnetic analysis, electron paramagnetic resonance, nuclear magnetic resonance, and nuclear gamma resonance [57,66-68].

A positive correlation was found between the content of $\mathrm{HM}$ and the $K$ value in the upper layer of soils in cities and industrial regions [1,69-76]. However, despite the long history of studying the relationship between the concentration of HM in soils and the value of $K$, a number of issues remain controversial and require clarification. In particular, the question of the unconditional effectiveness of measuring the $K$ for diagnosing the technogenic pollution of soils with HM remains controversial [77]. Parent rocks can be sources of HM in soils [12,78-83]. The carriers of HM in soils are not only iron compounds [12,54,84,85], but organic matter [44,54,85,86] and clay minerals [54,84,85], which do not have high $K$. In addition, anthropogenic impacts in cities lead to a change in the physicochemical properties of soils, which leads to the formation of geochemical barriers, on which many HMs accumulate, for example, on the territory of the largest Russian city, Moscow [87].

The soil cover of industrial cities of the Urals is subject to anthropogenic pollution by HM [88-94]. The population of industrial cities of the Perm region is negatively affected by high concentrations of HM in the environment $[88,93,95-100]$.

The products of the chemical processing of coal and its combustion in the territory of the cities of the Urals often lead to soil pollution with HM, which are part of the group of magnetic particles [101,102].

Until now, information on the elemental chemical composition of soils in Gubakha has been fragmentary. M.A. Shishkin and A.K Lapteva [94] analyzed the soil cover of the Kizelovsko-Gubakhinsky industrial district. They found that the soils of the city of Kizel accumulate $\mathrm{Cu}, \mathrm{Zn}$ and other metals. Abnormally high concentrations of $\mathrm{Cu}, \mathrm{Ni}$ and $\mathrm{Zn}$ were detected in the snow cover in the territory of Gubakha. I.S. Kopylov et al. [103] identified the Kosva hydrogeochemical anomalous zone located in the Kosva river basin. Anomalies for $\mathrm{Mn}, \mathrm{Be}, \mathrm{Cd}, \mathrm{Ni}, \mathrm{Cr}$ and $\mathrm{Pb}$ have been identified. There is a large geochemical anomalous zone in the basin of the middle reaches of the Kosva river. The genesis of the zone is natural and technogenic. There are areal anomalies of $\mathrm{Cu}, \mathrm{Pb}, \mathrm{Zn}, \mathrm{Mn}, \mathrm{Cr}, \mathrm{Ni}$, etc. E.A. Menshikova and B.M. Osovetsky [59] found that technogenic-alluvial deposits (near-channel shallow water of the Kosva river in Gubakha) contain up to 3\% of the magnetic fraction. The chemical composition of the magnetic fraction was $94-97 \% \mathrm{FeO}+\mathrm{F}_{2} \mathrm{O}_{3}, 0.1-0.3 \% \mathrm{TiO}_{2}, 0.06-0.13 \% \mathrm{Cr}_{2} \mathrm{O}_{3}$, $0.3-0.5 \mathrm{MnO}$ and $0.07-0.14 \% \mathrm{Ni}$.

The city Gubakha is part of the Kizelovsko-Gubakhinsky industrial district [94]. The leading industries in the city are chemical, fuel and energy, and metallurgy [104]. During 2014-2019, the average concentrations of suspended solids, Mn, Ni, Fe and Zn increased in Gubakha's atmospheric air [105-110]. Industrial enterprises OAO "Gubakhinsky coke" and the Kizelovskaya storage power station use coal from the Kuzbass deposit as raw material [104]. Coal of the Kuzbass deposit contains impurities of $\mathrm{Cr}, \mathrm{Mn}, \mathrm{Fe}, \mathrm{Co}, \mathrm{Ni}, \mathrm{Cu}, \mathrm{Zn}$, etc. [111]. The coke industry is considered the least known source of magnetic particles $[49,55]$. In connection with the above materials, the study of the elemental chemical composition of the soils of Gubakha using the methods of ecological magnetism is an urgent objective. 
The aim of this work was the ecological-geochemical assessment of the elemental chemical composition of the soils of Gubakha, and the establishment of the geochemical role of technogenic magnetic particles (TMPs).

\section{Materials and Methods}

Research area. The city of Gubakha is located in the eastern part of the Perm region, Russia. The city location coordinates are $58^{\circ} 52^{\prime} 00^{\prime \prime} \mathrm{N}, 57^{\circ} 35^{\prime} 00^{\prime \prime} \mathrm{E}$ (Figure 1 ). The relief of the area is hilly-ridged foothills, crossed by valleys of rivers and streams. The climate of the territory is moderately continental. In retrospective natural landscapes of the city, the parent rocks were eluvial and deluvial deposits formed from the weathering products of bedrock. The study area is located within the zone of the West-Ural fold, adjacent to the Cis-Ural trough. The territory is composed of Paleozoic rocks (from the Mid Devonian to the Cisuralian inclusive) and these overlap with Quaternary deposits [112].

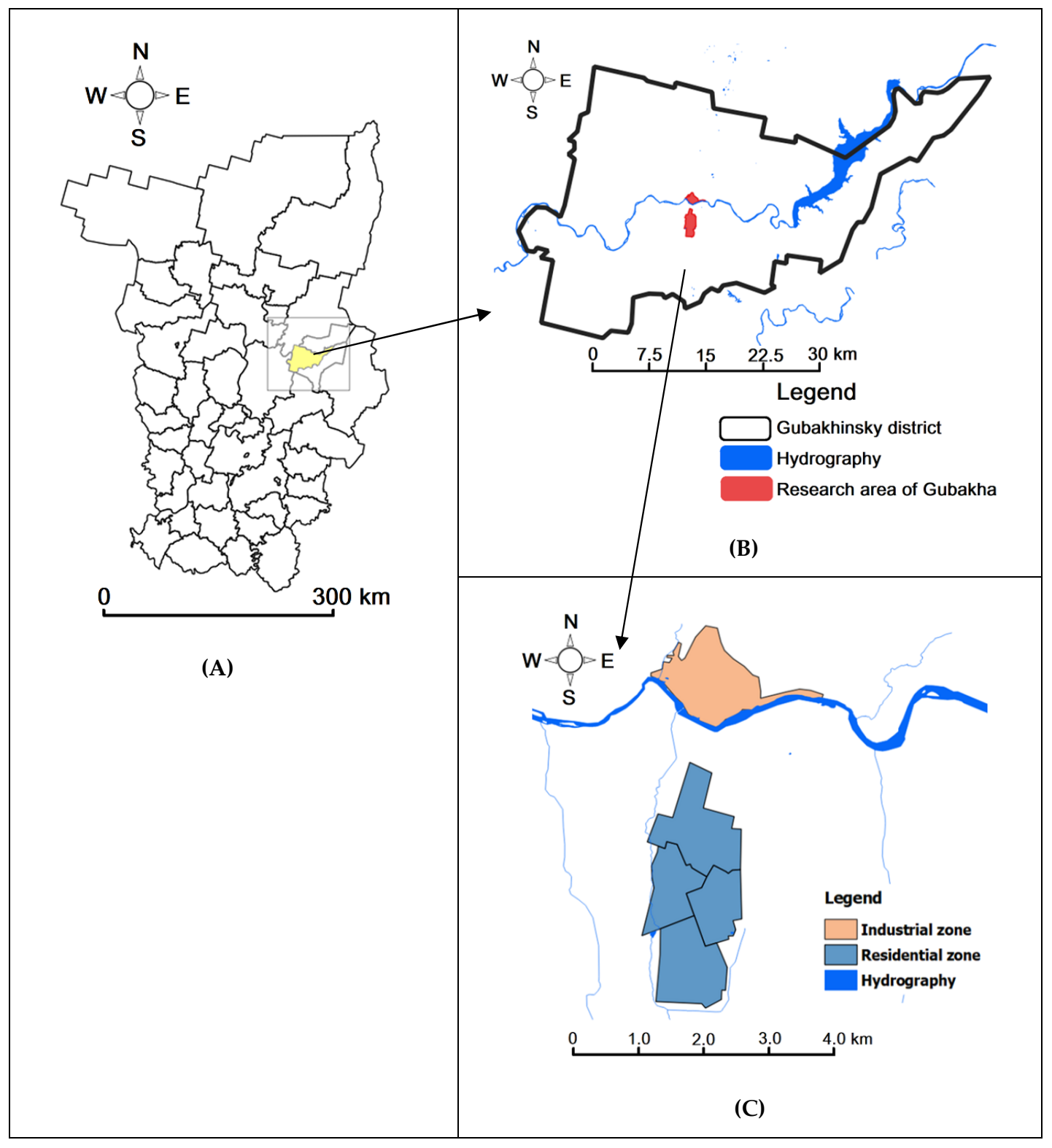

Figure 1. Research area: (A) Map of Perm region. (B) Gubskhinsky district. (C) Research zones of Gubakha. 
The vegetation on the natural landscapes is represented mainly by dark coniferous middle taiga and southern taiga foothill forests. Under natural conditions, the leading process of soil formation is the podzolic process. The predominant soils in the Gubakhinsky district are mountain Retisols [113,114]. On the territory of the city, anthropogenic soil formation is manifested and Urbic Technosol has been formed.

More than 33 thousand people live in Gubakha [115]. A distinctive feature of Gubakha is the fairly high concentration of industrial enterprises and population in a relatively small area. Industrial and residential areas alternate almost continuously for more than $25 \mathrm{~km}$. The residential area of the city is represented by $63.5 \%$ detached houses with personal plots, on the soils of which agricultural products are grown [116,117]. Railways, highways and six main gas pipelines pass through the district [118,119].

\subsection{Site Description and Sampling Strategy}

The objects of research were the Urbic Technosol Loamic, Eutric and Urbic Technosol Loamic, Skeletic [120] of the city of Gubakha, Perm region, Russia. Soil samples were taken out within the residential zone of the city inside residential areas and on roadside areas, as well as within the industrial zone in the area of operation of the production workshops of OAO "Gubakhinsky coke" (Figure 2). In total, 117 mixed samples from the $0-10 \mathrm{~cm}$ layer and 11 individual samples from two soil profiles (Urbic Technosol Loamic, Eutric and Urbic Technosol Loamic, Skeletic) were taken by the envelope method. Each mixed sample was taken from an area of $10 \mathrm{~m}^{2}$.

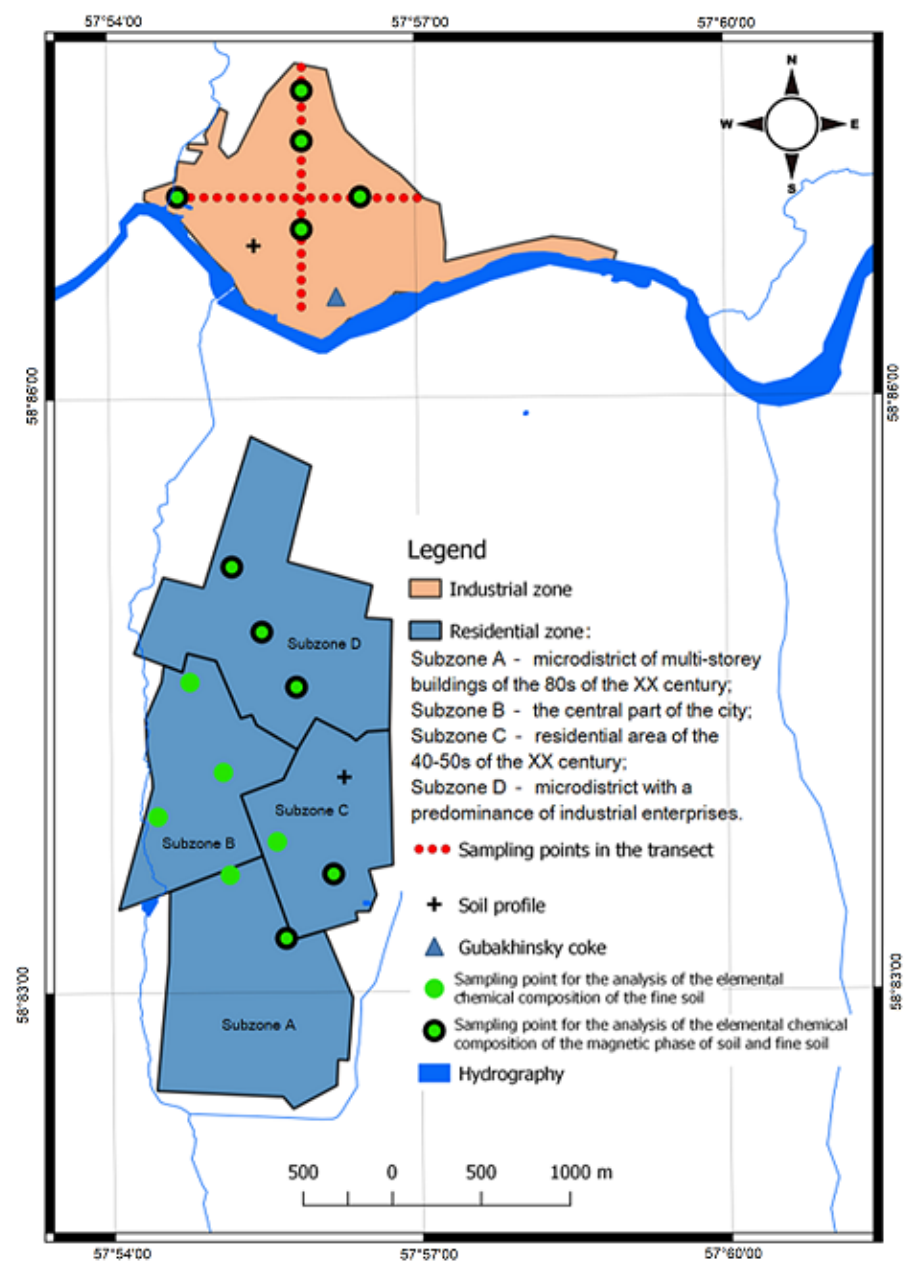

(A)

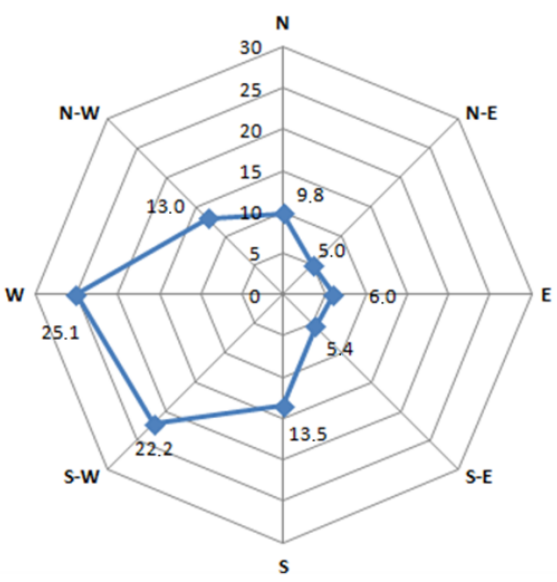

(B)

Figure 2. (A) Functional zoning scheme of the city territory. (B) Wind rose plot for Gubakha [121]. 
The residential zone of the city was divided into four subzones: subzone A-microdistrict of multi-story buildings of the 1980s (16 samples); subzone B-the central part of the city (15 samples); subzone C - residential area of the 1940-1950s (17 samples); subzone D-microdistrict with a predominance of industrial enterprises (12 samples) (Figure 2).

In the industrial zone of the city adjacent to the workshops of OAO "Gubakhinsky coke", 57 samples were taken in four transects with a length of $750 \mathrm{~m}$. The transects were laid along four cardinal points, and the sampling step was $50 \mathrm{~m}$ (Figure 2A). The winds throughout the year are southwest and west, with a prevailing speed 4-6 m/s (Figure 2B) [119].

Quantities of 1.2-1.5 kg of wet mixed (combined) soil samples were taken for research. The samples were homogenized, had roots removed, air dried, crushed and sieved through a $1.0 \mathrm{~mm}$ sieve. Granulometric composition, physicochemical properties, elemental chemical composition and magnetic susceptibility were determined for soil samples with particle size $<1.0 \mathrm{~mm}$.

A quantity of $300 \mathrm{~g}$ of soil sample with particle size $<1.0 \mathrm{~mm}$ was used to isolate the magnetic phase (MF). A hand-held permanent magnet "NdFeB" was applied for the "dry" separation method. The distance between the soil sample and the magnet surface was 5-10 $\mathrm{mm}$. The mineralogical, elemental chemical composition and magnetic susceptibility were studied for the magnetic phase.

Soil samples with particle sizes $>1.0 \mathrm{~mm}$ and the diamagnetic phase of the soil ("tail") were not used for detailed studies.

To carry out Mössbauer spectroscopy, we used a sample of the magnetic phase of the Urbic Technosol Loamic, Eutric in the residential zone of the city (subzone D), characterized by anomalously high $K$. The coordinates of the sampling site are $58^{\circ} 84^{\prime} 53^{\prime \prime} \mathrm{N}, 57^{\circ} 55^{\prime} 80^{\prime \prime} \mathrm{E}$.

\subsection{Analytical Methods}

The determination of physicochemical properties, the measurement of volumetric magnetic susceptibility $(K)$, and the magnetic separation of soil were carried out at the Department of Soil Science of the Perm State Agro-Technological University. The content organic carbon was determined using the Turin method. The sum of exchange bases was determined by the Kappen-Hillkowitz method. The hydrolytic acidity of the soil was determined by the Kappen method. The exchange acidity of the soil was determined by the method of TsINAO. The degree of soil saturation with bases and cation exchange capacity was determined according to Kappen-Hillkowitz [122]. The granulometric composition of the soil was determined by the Kachinsky pyrophosphate method. The boundaries between the six particle size classes were determined in accordance with Russian generally accepted fractional groups [123]. The coarse and medium sand fraction $(1-0.25 \mathrm{~mm})$ and the fine sand fraction $(0.25-0.05 \mathrm{~mm})$ were separated by sieving while more fine-grained fractions of the coarse, medium and fine silt $(0.05-0.01 \mathrm{~mm} ; 0.01-0.005 \mathrm{~mm}$ and $0.005-0.001 \mathrm{~mm}$, respectively) as well as the clay fraction $(<0.001 \mathrm{~mm})$ were determined by the pipette method after sample pretreatment with sodium pyrophosphate.

The choice of research HM was due to the earlier assessment by M.A. Shishkin and A.K Lapteva [94] of the geochemical state of the soil and snow cover of the Kizelovsko-Gubakhinsky industrial district. It was found that the priority environmental pollutants in this region of the Perm region were $\mathrm{Cu}, \mathrm{Zn}$, $\mathrm{Ni}, \mathrm{Zn}$ and $\mathrm{Mn}$.

The elemental chemical composition of soil (15 samples) and magnetic phase (10 samples) was determined by X-ray fluorescence at the Vernadsky Institute of Geochemistry and Analytical Chemistry of the Russian Academy of Sciences on an AXIOS Advanced spectrometer (PANalytical B.V., Holland). The X-ray tube of spectrometer had a Rh anode as the excitation source for characteristic radiation. The spectrometer was calibrated against 36 certified standard samples of bottom sediments, soils and rocks, including those of the SDO, SGKhM, SGKh, SKR, SDPS, and other sets, for which the calibration curves and concentrations of 25 elements were determined (ten major elements: $\mathrm{Na}, \mathrm{Mg}$, $\mathrm{Al}, \mathrm{Si}, \mathrm{P}, \mathrm{K}, \mathrm{Ca}, \mathrm{Ti}, \mathrm{Mn}$, and Fe; and fifteen minor and trace elements: S, V, Cr, Co, Ni, Cu, Zn, As, Rb, $\mathrm{Sr}, \mathrm{Y}, \mathrm{Zr}, \mathrm{Nb}, \mathrm{Ba}$, and $\mathrm{Pb}$ ). The standards were selected based on the tentative semiquantitative $\mathrm{XRF}$ 
analysis of four samples randomly selected from among those chosen for this research. The samples to be analyzed and the standards were prepared from $0.3 \mathrm{~g}$ portions of material mixed with $0.06 \mathrm{~g}$ of polystyrene $\mathrm{C}_{9} \mathrm{H}_{8}$, in the form of pellets $20 \mathrm{~mm}$ in diameter. The reproducibility and accuracy of the analyses were controlled by analyzing the standard sample SGKhM2. The comparison of our analyses and attested tabulated values testifies that the relative standard deviations do not exceed the values permissible for the analysis of ordinary samples in compliance with the accuracy standards stipulated in OST 41-08-205-99 [124].

$K$ was determined using a KT-6 kappameter (Czech Republic). The sensitivity of the equipment was $1 \times 10^{-5}$ SI units, and the measuring ranges varied from -9.99 to $99.9910^{-5}$ SI units.

The forms of iron were determined in the laboratory of soil reclamation of the Institute of Soil Science and Agrochemistry of the Siberian Branch of the Russian Academy of Sciences. Iron was subdivided into forms and fractions, according to the classification of S.V. Zonn [125]. Silicate and non-silicate iron and amorphous forms of iron were identified. The total iron content $\left(\mathrm{Fe}_{\text {total }}\right)$, non-silicate or free iron was extracted from the soil by the Mehr and Jackson method, modified according to Coffin [126]. The iron in the Mera-Jackson and Tamm extracts was determined in the presence of sulfosalicylic acid by the colorimetric method on a photocolorimeter KFK-2MP (Russia). The light transmission coefficient of the device was from 100 to $1 \%$, and the measurement error was $1 \%$.

The above research methods were carried out 3 times.

The analysis of the particles of the magnetic phase was carried out by microprobe and X-ray phase methods at the Borok Geophysical Observatory of the Institute of Physics of the Earth, O.Yu. Schmidt Russian Academy of Sciences. The particles selected for study on a microprobe were applied onto a double-sided conductive carbon tape and rolled with a glass rod so that the surface of the particles was oriented parallel to the surface of the stage. The composition of the particles was determined by the method of local X-ray spectral microanalysis. We used a Tescan Vega II XMU scanning electron microscope (Tescan, Czech Republic) equipped with an INCA Energy 450 X-ray spectral microanalysis system with an INCAx-sight X-ray spectrometer (Oxford Instruments, England) and the INCA Energy + software platform. The range of elements to be determined was from Be to $\mathrm{U}$. The conditions of analysis performed only on an energy dispersive spectrometer were as follows: accelerating voltage $20 \mathrm{kV}$, current of absorbed electrons on Co $0.3 \mathrm{nA}$, analysis time at a point of $70 \mathrm{~s}$. When a crystal diffraction spectrometer was used together with an energy-dispersive spectrometer, the analysis conditions were different-an accelerating voltage of $20 \mathrm{kV}$, a current of absorbed electrons on Co of $20 \mathrm{nA}$, and the total analysis time at a point was $170 \mathrm{~s}$. The detection limit for the elements to be determined was in the range of 0.1-1.0 mass $\%$. The determination accuracy was 0.2 mass $\%$ of the element. A total of 83 energy dispersive spectra were obtained and analyzed at different points of the soil magnetic phase samples.

In the laboratory of Mössbauer spectroscopy of the Department of Technology of Materials for Electronics of National Research Technological University "Moscow Institute of Steel and Alloys" (MISiS, Moscow, Russia), a sample of the magnetic phase, extracted from the soil of the village part of the city, was studied. For the analysis, we used a Mössbauer spectrometer Ms-1104 Em operating in a constant acceleration mode with a Co57 g-radiation source. The measurements were carried out at room temperature. Mössbauer spectra were recorded in 512 computer channels and processed using the Univem Ms program. The criterion for the best decomposition of the Mössbauer spectrum into components was min $\chi^{2}$, which estimates the approximation of the calculated spectrum to the experimental one. The isomeric shift was calculated relative to $\alpha$-Fe. Samples weighing 100-200 mg were ground in an agate mortar to a particle size of $0.05 \mathrm{~mm}$.

\subsection{Ecological-Geochemical Assessment}

For the geochemical assessment of the state of soils, the following formulas were used:

- $\quad$ Coefficient of enrichment-impoverishment of the magnetic phase in heavy metals $\left(\mathrm{KK}_{\mathrm{m} . \mathrm{f} .}\right)$ : 


$$
\mathrm{KK}_{\text {m.f. }}=\frac{\mathrm{C}_{\mathrm{m} . \mathrm{f}}}{\mathrm{C}_{\mathrm{s}}}
$$

$\mathrm{C}_{\mathrm{m} . \mathrm{f} .}$ - concentration of the i-th chemical element in the magnetic phase of the soil, ppm;

$\mathrm{C}_{\mathrm{s}}$ - concentration of the i-th chemical element in the soil, ppm.

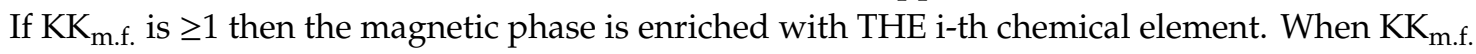
is $<1$ then the magnetic phase is impoverishment with THE i-th chemical element.

- Geo-accumulation Index $\left(\mathrm{I}_{\text {geo }}\right)$ [127]:

$$
\mathrm{I}_{\text {geo }}=\log _{2} \frac{\mathrm{C}_{1}}{1.5 \mathrm{C}_{2}}
$$

$\mathrm{C}_{1}$-concentration of the i-th chemical element in the soil component (soil, magnetic phase), ppm;

$\mathrm{C}_{2}$ - concentration of the i-th chemical element in the background soil, ppm;

1.5-the constant is used as a factor to minimize possible variations in the background values due to lithogenic effects.

The contamination categories based on the $\mathrm{I}_{\text {geo }}$ are classified as below: uncontaminated ( $\left.\mathrm{I}_{\text {geo }} \leq 0\right)$; uncontaminated to moderately contaminated $\left(0<\mathrm{I}_{\text {geo }} \leq 1\right)$; moderately contaminated $\left(1<\mathrm{I}_{\text {geo }} \leq 2\right)$; moderately to heavily contaminated $\left(2<\mathrm{I}_{\text {geo }} \leq 3\right)$; heavily contaminated $\left(3<\mathrm{I}_{\text {geo }} \leq 4\right)$; heavily to extremely contaminated $\left(4<\mathrm{I}_{\text {geo }} \leq 5\right)$; and extremely contaminated $\left(\mathrm{I}_{\text {geo }}>5\right)$.

- Coefficient of concentration relative to the background $\left(\mathrm{KK}_{\mathrm{B}}\right)$ [128]:

$$
\mathrm{KK}_{\mathrm{B}}=\frac{\mathrm{C}_{1}}{\mathrm{C}_{2}}
$$

- Coefficient of concentration relative to the clarke of soils of residential landscapes according to V.A. Alekseenko $\left(\mathrm{KK}_{\mathrm{A}}\right)$ [129]:

$$
\mathrm{KK}_{\mathrm{A}}=\frac{\mathrm{C}_{\mathrm{S}}}{\mathrm{C}_{3}}
$$

$\mathrm{C}_{3}$-clarke of the i-th chemical element of the soil of residential landscapes in Russia according to V.A. Alekseenko, ppm [129].

When using $\mathrm{KK}_{\mathrm{B}}$ and $\mathrm{KK}_{\mathrm{A}}$, the pollution is classified as follows: $\leq 1$ unpolluted soil, $>1$ polluted soil.

- $\quad$ Pollution load index (PLI) [130]:

$$
\text { PLI }=\sqrt[i]{\mathrm{CF}_{1} \times \mathrm{CF}_{1} \times \ldots \times \mathrm{CF}_{\mathrm{i}}}
$$

$\mathrm{CF}_{\mathrm{i}}$-concentration factor of the $\mathrm{i}$-th chemical element of sample in the soil component (soil, magnetic phase).

$\mathrm{i}$ - the number of metals studied (six in this study).

When using PLI, the pollution is classified as follows: PLI $\leq 1$ low level of pollution; $1<\mathrm{PLI} \leq 2$ moderate level of pollution; $2<\mathrm{PLI} \leq 5$ high level of pollution; PLI $>5$ extremely high level of pollution.

The forms of iron compounds in the soil were calculated using the following formulas [126]:

- $\quad$ Silicate iron $\left(\mathrm{Fe}_{\mathrm{s}}\right)$ :

$$
\mathrm{Fe}_{\mathrm{s}}=\mathrm{Fe}_{\text {total }}-\mathrm{Fe}_{\mathrm{ns}}
$$

$\mathrm{Fe}_{\text {total }}$-total iron content in the test sample, \%;

$\mathrm{Fe}_{\mathrm{ns}}$-iron of non-silicate compounds were determined by the Mehr and Jackson method, \%. 
- Crystallized iron compounds $\left(\mathrm{Fe}_{\mathrm{c}}\right)$ [126]:

$$
\mathrm{Fe}_{\mathrm{c}}=\mathrm{Fe}_{\mathrm{ns}}-\mathrm{Fe}_{\mathrm{am}}
$$

$\mathrm{Fe}_{\mathrm{am}}$-contents of iron amorphous compounds were determined by Tamm method, \%.

- $\quad$ Schwertman's criterion (SC) [131]:

$$
\mathrm{SC}=\frac{\mathrm{Fe}_{\mathrm{am}}}{\mathrm{Fe}_{\mathrm{ns}}}
$$

- The degree of development of oxidogenesis (DO) [132]:

$$
\mathrm{DO}=\frac{\mathrm{Fe}_{\mathrm{ns}}}{\mathrm{Fe}_{\text {total }}}
$$

Statistical processing of the research results was carried out in the MS Office 2010 software package according to E. A. Dmitriev [133].

\section{Results}

\subsection{Soil Morphology}

Soil profile 1. Urbic Technosol Loamic, Eutric ( $58^{\circ} 84^{\prime} 08^{\prime \prime} \mathrm{N}, 57^{\circ} 56^{\prime} 24^{\prime \prime}$ E). Territory-a courtyard square in the residential zone of Gubakha. The total depth of profile is $102 \mathrm{~cm}$. Profile structure: O-AYur,lo-Eur,lo-EBTur,ce-Btur,ce-BTCurcesk-Cce,sk.

Soil profile 2. Urbic Technosol Loamic, Skeletic formed on mixed soils underlain by eluvium of Permian clays ( $\left.58^{\circ} 86^{\prime} 77^{\prime \prime} \mathrm{N}, 57^{\circ} 55^{\prime} 44^{\prime \prime} \mathrm{E}\right)$. The section was laid $385 \mathrm{~m}$ west of the Gubakha railway station, and 220 m northeast of the river Kosva. Profile structure: O-AYur,lo-Eur,lo-EBTur,ce,sk-BTur,ce,sk-Cce,sk. In the AYur,lo horizon for both soils there are inclusions of construction waste and angular coal particles with a diameter of up to $10-20 \mathrm{~mm}$.

\subsection{Soil Granulometry}

The content of physical clay is $49.92 \%$ in the Urbic Technosol Loamic, Eutric, and in the Urbic Technosol Loamic, Skeletic, it is $45.44 \%$. Thus, the studied soils belong to heavy, loamy varieties [123]. In both soils, coarse dust predominates among mechanical fractions, constituting 31.32 and $32.52 \%$,

\begin{tabular}{|c|c|c|c|c|c|c|c|c|}
\hline \multirow{2}{*}{ Horizon, Depth, cm } & \multicolumn{7}{|c|}{ Particle Size, mm; Content, $\%$} & \multirow{2}{*}{ Granulometry } \\
\hline & $1-0.25$ & $0.25-0.05$ & $0.05-0.01$ & 0.01-0.005 & $0.005-0.001$ & $<0.001$ & $\sum<0.01$ & \\
\hline \multicolumn{9}{|c|}{ Profile 1. Urbic Technosol Loamic, Eutric } \\
\hline AYur,lo (7-22) & 2.89 & 15.87 & 31.32 & 7.27 & 12.53 & 30.12 & 49.92 & heavy loamy \\
\hline \multicolumn{9}{|c|}{ Profile 2. Urbic Technosol Loamic, Skeletic } \\
\hline AYur,lo (5-12) & 1.66 & 20.38 & 32.52 & 22.64 & 19.84 & 2.96 & 45.44 & heavy loamy \\
\hline
\end{tabular}
respectively, and medium sand presents in a minimum amount (Table 1).

Table 1. Granulometry of the upper soil horizons of soils of Gubakha.

The horizons AYur,lo and Eur,lo are depleted in silt, fine dust and coarse dust, and are enriched with medium dust and medium sand compared to the underlying horizons (Figure 3). 


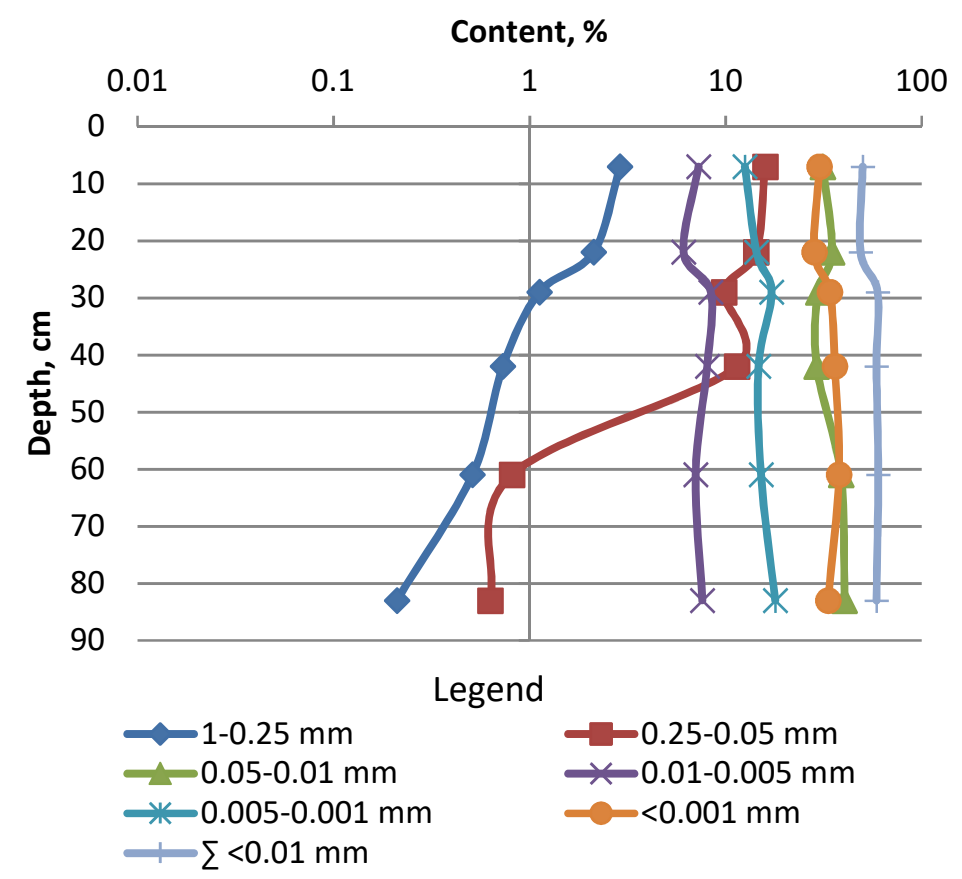

Figure 3. Profile distribution of fractions of mechanical elements in the Urbic Technosol Loamic, Eutric of the residential zone of Gubakha.

\subsection{Selected Chemical Data}

The contents of organic carbon $\left(\mathrm{C}_{\mathrm{org}}\right)$, mobile aluminum and hydrogen are higher in the surface horizons of the profiles than in the parent rock. The degree of soil saturation with bases increases with depth (Table 2).

Table 2. Physicochemical properties of soil of Gubakha.

\begin{tabular}{|c|c|c|c|c|c|c|c|c|c|}
\hline \multirow{2}{*}{ Horizon, Depth, cm } & \multirow{2}{*}{$\mathrm{C}_{\text {org }} \%$} & $\mathrm{~S}$ & $\mathbf{H}_{\mathbf{h}}$ & $\mathbf{H}_{\mathbf{e x}}$ & Al & CEC & \multirow{2}{*}{ Degree of Base Saturation, \% } & \multirow{2}{*}{$\mathrm{pH}_{\mathrm{KCl}}$} & \multirow{2}{*}{$\mathrm{pH}_{\mathrm{H} 2 \mathrm{O}}$} \\
\hline & & \multicolumn{5}{|c|}{$\mathrm{cmol}_{\mathrm{c}} / \mathrm{kg}$} & & & \\
\hline \multicolumn{10}{|c|}{ Profile 1. Urbic Technosol Loamic, Eutric } \\
\hline AYur,lo (7-22) & 2.7 & 11.5 & 6.8 & 2.7 & 1.4 & 18.3 & 63 & 3.6 & 4.7 \\
\hline Eur,lo (22-29) & - & 8.3 & 7.5 & 2.2 & 0.3 & 15.8 & 52 & 3.7 & 4.8 \\
\hline EBTur,ce (29-42) & - & 12.8 & 9.1 & 2.0 & 0.3 & 21.9 & 58 & 4.1 & 5.1 \\
\hline BTur,ce (42-61) & - & 14.5 & 7.2 & 1.7 & 0.3 & 21.7 & 67 & 4.5 & 5.6 \\
\hline BTCur,ce,sk (61-83) & - & 15.8 & 6 & 1.3 & 0.2 & 21.8 & 73 & 4.8 & 5.8 \\
\hline Cce,sk (83-102) & 0.2 & 12.3 & 4.9 & 0.7 & 0.1 & 17.2 & 71 & 4.9 & 5.9 \\
\hline \multicolumn{10}{|c|}{ Profile 2. Urbic Technosol Loamic, Skeletic } \\
\hline AYur,lo (5-12) & 2.0 & 15.8 & 7.5 & 3.2 & 0.4 & 23.3 & 68 & 5.6 & 4.5 \\
\hline Eur,lo (12-30) & - & 12.5 & 6.7 & 2.7 & 0.3 & 19.2 & 65 & 5.1 & 4.1 \\
\hline EBTur,ce,sk (30-50) & - & 16.3 & 8.2 & 2.5 & 0.4 & 24.5 & 66 & 3.8 & 2.8 \\
\hline BTur,ce,sk (50-70) & - & 15.8 & 8.9 & 2.1 & 0.1 & 24.7 & 64 & 3.8 & 2.8 \\
\hline Cce,sk (70-90) & 0.2 & 14.5 & 5.6 & 0.9 & 0.1 & 20.1 & 72 & 3.5 & 2.6 \\
\hline
\end{tabular}

Note: "-"-the indicator was not determined.

In the residential zone of the city, the physicochemical properties of the surface soil horizons in the territory of the courtyards of residential buildings and squares are heterogeneous, and vary within the following limits: exchangeable soil acidity $\left(\mathrm{pH}_{\mathrm{KCl}}\right)$ 3.3-8.0; organic carbon 1.0-3.9\%; sum of exchange bases (S) $8.7-13.2 \mathrm{cmol}_{\mathrm{c}} / \mathrm{kg}$; hydrolytic acidity $\left(\mathrm{H}_{\mathrm{h}}\right) \quad 0.8-6.0 \mathrm{cmol}_{\mathrm{c}} / \mathrm{kg}$; cation exchange capacity (CEC) $1.6-15.9 \mathrm{cmol}_{\mathrm{C}} / \mathrm{kg}$. For roadside territories of the residential zone, the indicators changed in the following ranges: exchangeable soil acidity 3.2-7.8; organic carbon $0.8-3.9 \%$; sum of exchange bases $8.9-11.9 \mathrm{cmol}_{\mathrm{c}} / \mathrm{kg}$; hydrolytic soil acidity $6.3-9.1 \mathrm{cmol}_{\mathrm{c}} / \mathrm{kg}$; cation exchange capacity $15.8-20.2 \mathrm{cmol}_{\mathrm{c}} / \mathrm{kg}$. 
The highest variability was found for the organic carbon content and exchangeable acidity of the soil, and the indicators of the absorption capacity of the soil vary to a lesser extent (Table 3).

Table 3. Statistical parameters of the physical and chemical properties of the upper soil horizons $(0-10 \mathrm{~cm})$ of the residential zone of Gubakha $(p=0.05)$.

\begin{tabular}{cccccccc}
\hline Sampling Location & Parameters & $\mathbf{N}$ & $\mathbf{M}$ & $\pm \mathbf{m}$ & $\mathbf{M i n}$ & $\mathbf{M a x}$ & $\mathbf{V}, \mathbf{\%}$ \\
\hline \multirow{5}{*}{ Territories within } & $\mathrm{pH}_{\mathrm{KCl}}$ & 33 & 5.2 & 2.3 & 3.3 & 8.0 & 29 \\
residential areas & $\mathrm{C}_{\text {org }}$ & 33 & 2.1 & 0.6 & 1.0 & 3.9 & 28 \\
& $\mathrm{~S}$ & 33 & 10.7 & 1.0 & 8.7 & 13.2 & 9 \\
& $\mathrm{H}_{\mathrm{h}}$ & 33 & 7.4 & 0.8 & 6.0 & 9.5 & 12 \\
& $\mathrm{CEC}$ & 33 & 18.1 & 1.6 & 15.9 & 20.6 & 7 \\
\hline \multirow{5}{*}{ Roadside areas } & $\mathrm{pH}_{\mathrm{KCl}}$ & 27 & 5.1 & 2.5 & 3.2 & 7.8 & 31 \\
& $\mathrm{C}_{\mathrm{org}}$ & 27 & 2.3 & 1.0 & 0.9 & 3.9 & 34 \\
& $\mathrm{~S}$ & 27 & 10.4 & 0.7 & 8.9 & 11.9 & 8 \\
& $\mathrm{H}_{\mathrm{h}}$ & 27 & 7.4 & 0.6 & 6.3 & 9.1 & 11 \\
& $\mathrm{CEC}$ & 27 & 17.9 & 1.2 & 15.8 & 20.2 & 6 \\
\hline
\end{tabular}

In the surface soil horizons in the industrial zone, the organic carbon content is $1.2-3.4 \%$, and the exchangeable soil acidity $\left(\mathrm{pH}_{\mathrm{KCl}}\right)$ is $3.1-7.6$ (Table 4$)$.

Table 4. Statistical parameters of the physical and chemical properties of the upper soil horizons $(0-10 \mathrm{~cm})$ of the industrial zone in the area of OAO "Gubakhinsky coke" $(p=0.05)$.

\begin{tabular}{cccccccc}
\hline Direction from the Factory & Parameters & $\mathbf{N}$ & $\mathbf{M}$ & $\pm \mathbf{m}$ & $\mathbf{M i n}$ & $\mathbf{M a x}$ & $\mathbf{V}, \mathbf{\%}$ \\
\hline 1 transect & $\mathrm{C}_{\mathrm{org}}$ & 15 & 2.5 & 0.1 & 1.8 & 3.4 & 11 \\
(North) & $\mathrm{pH}_{\mathrm{KCl}}$ & 15 & 5.1 & 0.4 & 3.3 & 7.6 & 13 \\
\hline 2 transect & $\mathrm{C}_{\mathrm{org}}$ & 15 & 2.3 & 0.2 & 1.5 & 3.2 & 12 \\
(East) & $\mathrm{pH}_{\mathrm{KCl}}$ & 15 & 4.6 & 0.2 & 3.2 & 6.1 & 11 \\
\hline 3 transect & $\mathrm{C}_{\text {org }}$ & 15 & 2.4 & 0.1 & 1.7 & 3.2 & 10 \\
(South) & $\mathrm{pH}_{\mathrm{KCl}}$ & 15 & 4.6 & 0.2 & 3.3 & 6.1 & 11 \\
\hline 4 transect & $\mathrm{C}_{\mathrm{org}}$ & 15 & 2.0 & 0.1 & 1.2 & 2.8 & 9 \\
(West) & $\mathrm{pH}_{\mathrm{KCl}}$ & 15 & 4.4 & 0.2 & 3.1 & 6.2 & 10 \\
\hline
\end{tabular}

\subsection{Mineralogical Composition}

\subsubsection{Forms of Iron Compounds in Soil}

Iron in the soil forms its own minerals, and is also a part of silicates. The total iron content in the soil in the microdistrict of high-rise buildings of the $1980 \mathrm{~s}$ is within $5.28-6.34 \%$, in the central part of the city $5.58-15.59 \%$, in the residential area of the $1940-1950$ s $5.73-7.17 \%$, and in the microdistrict with a predominance of industrial enterprises it is $4.72-6.79 \%$. The content of silicate iron in the studied soil samples varies from 0.23 to $13.13 \%$, and is on average $4.23 \%$. This is slightly more than half of the gross iron content-on average $53.16 \%$, and in some cases reaching $84.22 \%$. The degree of development of oxidogenesis (DO) varies from 0.16 to 0.95 . The average content of crystallized iron compounds $\left(\mathrm{Fe}_{\mathrm{c}}\right)$ is $3.67 \%$, and the maximum is $4.56 \%$. The Schwertman's criterion (SC) is less than 1.0 in all studied samples (Table 5).

The Schwertmann's criterion in all the studied samples was less than one unit (Table 5). 
Table 5. Forms of iron compounds in soil of surface horizons $(0-10 \mathrm{~cm})$ of Gubakha.

\begin{tabular}{|c|c|c|c|c|c|c|c|c|}
\hline \multirow{2}{*}{ Sampling Location } & \multirow{2}{*}{ № samples } & \multirow{2}{*}{$\mathrm{Fe}_{\text {total }}, \%$ * } & \multicolumn{3}{|c|}{$\mathrm{Fe}_{\mathrm{ns}}, \%$} & \multirow{2}{*}{$\mathrm{Fe}_{\mathrm{s}}, \%$} & \multirow{2}{*}{ DO } & \multirow{2}{*}{ SC } \\
\hline & & & $\mathrm{Fe}_{\mathbf{a m}}$ & $\mathrm{Fe}_{\mathrm{c}}$ & $\sum$ & & & \\
\hline \multirow{4}{*}{$\begin{array}{l}\text { Microdistrict of multi-storey } \\
\text { buildings of the 1980s }\end{array}$} & \multirow{2}{*}{2} & 5.28 & 0.04 & 3.49 & 3.54 & 1.74 & \multirow{2}{*}{0.67} & \multirow{2}{*}{0.01} \\
\hline & & $\overline{100}$ & $\overline{0.83}$ & $\overline{66.14}$ & $\overline{66.97}$ & $\overline{33.03}$ & & \\
\hline & \multirow{2}{*}{7} & $\underline{6.34}$ & $\underline{0.04}$ & $\underline{3.58}$ & 3.62 & $\underline{2.72}$ & \multirow{2}{*}{0.57} & \multirow{2}{*}{0.01} \\
\hline & & $\overline{100}$ & $\overline{0.68}$ & $\overline{56.48}$ & $\overline{57.16}$ & $\overline{42.84}$ & & \\
\hline \multirow{6}{*}{$\begin{array}{c}\text { The central part } \\
\text { of the city }\end{array}$} & \multirow{2}{*}{15} & 15.59 & 0.07 & 2.39 & 2.46 & 13.13 & \multirow{2}{*}{0.16} & \multirow{2}{*}{0.03} \\
\hline & & $\overline{100}$ & $\overline{0.45}$ & $\overline{15.33}$ & $\overline{15.78}$ & $\overline{84.22}$ & & \\
\hline & \multirow{2}{*}{20} & 5.58 & 0.05 & 4.56 & 4.62 & 0.96 & \multirow{2}{*}{0.83} & \multirow{2}{*}{0.01} \\
\hline & & $\overline{100}$ & $\overline{0.97}$ & $\overline{81.76}$ & $\overline{82.72}$ & $\overline{17.28}$ & & \\
\hline & \multirow{2}{*}{21} & 16.15 & 0.14 & 3.36 & 3.50 & 12.65 & \multirow{2}{*}{0.22} & \multirow{2}{*}{0.04} \\
\hline & & $\overline{100}$ & $\overline{0.84}$ & $\overline{20.81}$ & $\overline{21.65}$ & $\overline{78.35}$ & & \\
\hline \multirow{4}{*}{$\begin{array}{l}\text { Residential area of the } \\
\text { 1940-1950s }\end{array}$} & \multirow{2}{*}{22} & 5.73 & 0.04 & 3.24 & 3.28 & 2.45 & \multirow{2}{*}{0.57} & \multirow{2}{*}{0.01} \\
\hline & & $\overline{100}$ & $\overline{0.63}$ & $\overline{56.61}$ & $\overline{57.24}$ & $\overline{42.76}$ & & \\
\hline & \multirow{2}{*}{30} & $\underline{7.17}$ & $\underline{0.04}$ & $\underline{4.14}$ & $\underline{4.18}$ & 2.99 & \multirow{2}{*}{0.58} & \multirow{2}{*}{0.01} \\
\hline & & $\overline{100}$ & $\overline{0.56}$ & $\overline{57.8}$ & $\overline{58.35}$ & $\overline{41.65}$ & & \\
\hline \multirow{6}{*}{$\begin{array}{l}\text { Microdistrict with a } \\
\text { predominance of industrial } \\
\text { enterprises }\end{array}$} & \multirow{2}{*}{37} & $\underline{6.16}$ & $\underline{0.03}$ & $\underline{4.19}$ & $\underline{4.23}$ & $\underline{1.93}$ & \multirow{2}{*}{0.69} & 001 \\
\hline & & $\overline{100}$ & $\overline{0.54}$ & $\overline{68.1}$ & $\overline{68.64}$ & $\overline{31.36}$ & & 0.01 \\
\hline & & 4.72 & 0.04 & $\underline{4.44}$ & 4.49 & 0.23 & & \\
\hline & 38 & $\overline{100}$ & $\overline{0.95}$ & $\overline{94.13}$ & $\overline{95.08}$ & $\overline{4.92}$ & 0.95 & 0.01 \\
\hline & & 6.79 & 0.05 & 3.27 & 3.32 & 3.47 & & \\
\hline & 42 & $\overline{100}$ & 0.72 & 48.23 & 48.95 & 51.05 & 0.49 & 0.02 \\
\hline
\end{tabular}

Note: ${ }^{*}$-The numerator contains $\%$ of the soil mass, and the denominator contains $\%$ of the gross iron content in soils.

\subsubsection{Magnetic Susceptibility}

The maximum values of $K, 84$ and $99 \times 10^{-5}$ SI, were revealed in the AYur,lo horizons of soils (Figure 4). The $K$ values decrease two to three times with depth. The minimum $K$ values are typical for parent rocks -28 and $48 \times 10^{-5} \mathrm{SI}$. A slight increase in $K$ was noted at a depth of $60 \mathrm{~cm}$, which is associated with variations in $K$ in the parent rock. The skeletal part of the soil consists of construction waste-limestone crushed stone and wood inclusions, which have a low $K$. The geogenic factor is of secondary importance in the formation of the susceptibility of the surface soil horizons of Gubakha.

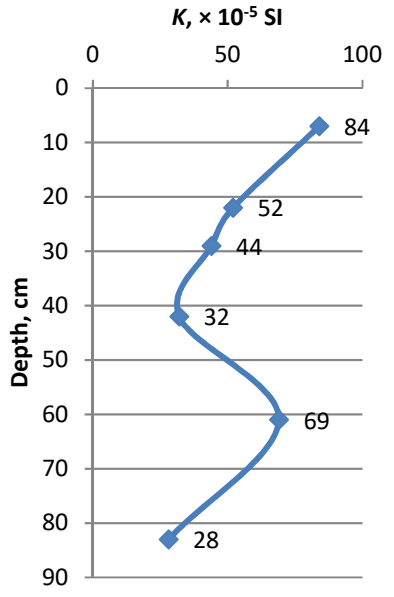

(A)

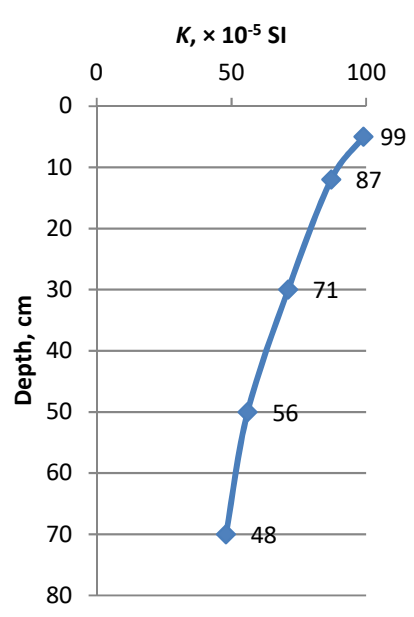

(B)

Figure 4. Intraprofile distribution of magnetic susceptibility in the soils of the city of Gubakha: (A) Urbic Technosol Loamic, Eutric; (B) Urbic Technosol Loamic, Skeletic. 
The average $K$ value is $169 \times 10^{-5}$ SI for the soils of the roadside territories of the residential zone, and for the territory within the residential areas it is $120 \times 10^{-5}$ SI (Table 6).

Table 6. Statistical parameters of the magnetic susceptibility of the upper soil horizons $(0-10 \mathrm{~cm})$ of the residential zone of Gubakha, $\times 10^{-5}$ SI $(p=0.05)$.

\begin{tabular}{ccccccc}
\hline Sampling Location & $\mathbf{n}$ & $\mathbf{M}$ & $\pm \mathbf{m}$ & $\mathbf{m i n}$ & $\mathbf{M a x}$ & $\mathbf{V ,} \%$ \\
\hline Territories within residential areas & 33 & 120 & 127 & 1 & 416 & 94 \\
Roadside areas & 27 & 169 & 273 & 70 & 627 & 98 \\
\hline
\end{tabular}

In the soils of the industrial zone of the city, the individual single values of $K$ are relatively high and amount to $462-544 \times 10^{-5} \mathrm{SI}$.

On the territory adjacent to the workshops of OAO "Gubakhinsky coke", the highest $K$ was found in soils within a radius of up to $500 \mathrm{~m}$ from the production workshops of the plant. The average $K$ of soils in these sections of the transects is $267 \times 10^{-5}$ SI. The $K$ of soil decreases with distance from the production workshops of OAO "Gubakhinsky coke". The K of soils is $120 \times 10^{-5} \mathrm{SI}$ in the interval from 500 to $1000 \mathrm{~m}$. The $K$ values are $\leq 57 \times 10^{-5} \mathrm{SI}$ in the range from 1000 to $1500 \mathrm{~m}$.

The $K$ is more varied in the north and east of the sources of magnetic particle emissions than in the south and east. The $K$ ranges from $126 \pm 15 \times 10^{-5} \mathrm{SI}$ in the westerly direction to $186 \pm 61 \times 10^{-5} \mathrm{SI}$ in the north (Table 7).

Table 7. Statistical parameters of the magnetic susceptibility of the upper soil horizons $(0-10 \mathrm{~cm})$ of the industrial zone in the area of OAO "Gubakhinsky coke", $\times 10^{-5}$ SI $(p=0.05)$.

\begin{tabular}{ccccccc}
\hline Direction from the Factory & $\mathbf{n}$ & $\mathbf{M}$ & $\pm \mathbf{m}$ & $\mathbf{M i n}$ & $\mathbf{M a x}$ & $\mathbf{V}, \mathbf{\%}$ \\
\hline 1 transect (North) & 15 & 186 & 61 & 27 & 544 & 42 \\
2 transect (East) & 15 & 137 & 32 & 23 & 464 & 41 \\
3 transect (South) & 15 & 142 & 22 & 30 & 401 & 33 \\
4 transect (West) & 15 & 126 & 15 & 27 & 330 & 31 \\
\hline
\end{tabular}

The $K$ values of the soil and magnetic phases are significantly different from each other (Table 8 ). The $K$ of the magnetic phase varies within $2862-16,470 \times 10^{-5} \mathrm{SI}$ in the residential zone of city, and in the industrial zone it is $5600-7300 \times 10^{-5} \mathrm{SI}$.

Table 8. Statistical indicators of the magnetic susceptibility of soil and magnetic phase of the upper soil horizons $(0-10 \mathrm{~cm})$ of Gubakha $(p=0.05)$.

\begin{tabular}{cccccccc}
\hline Sampling Location & Soil Component & $\mathbf{n}$ & $\mathbf{M}$ & $\pm \mathbf{m}$ & $\mathbf{M i n}$ & $\mathbf{M a x}$ & $\mathbf{V}, \mathbf{\%}$ \\
\hline \multirow{2}{*}{ Residential zone } & Soil before magnetic separation & 5 & 328 & 88 & 90 & 627 & 60 \\
& magnetic phase & 5 & 10,816 & 2291 & 2862 & 16,470 & 47 \\
\hline \multirow{2}{*}{ Industrial zone } & Soil before magnetic separation & 5 & 148 & 31 & 42 & 216 & 46 \\
& magnetic phase & 5 & 6440 & 286 & 5600 & 7300 & 10 \\
\hline
\end{tabular}

3.4.3. Morphology, Mineralogical and Elemental Chemical Composition of Magnetic Phase Particles according to ESEM/EDS Results

In the magnetic phase of the soil of the Urbic Technosol Loamic, Eutric and the Urbic Technosol Loamic, Skeletic of Gubakha, microparticles of various shapes and mineralogical compositions were revealed (Figure 5). The magnetic phase contains particles of spherical, rounded, detrital, and irregular shapes. Spherical particles prevail in the industrial zone of the city (Figure 5B). 

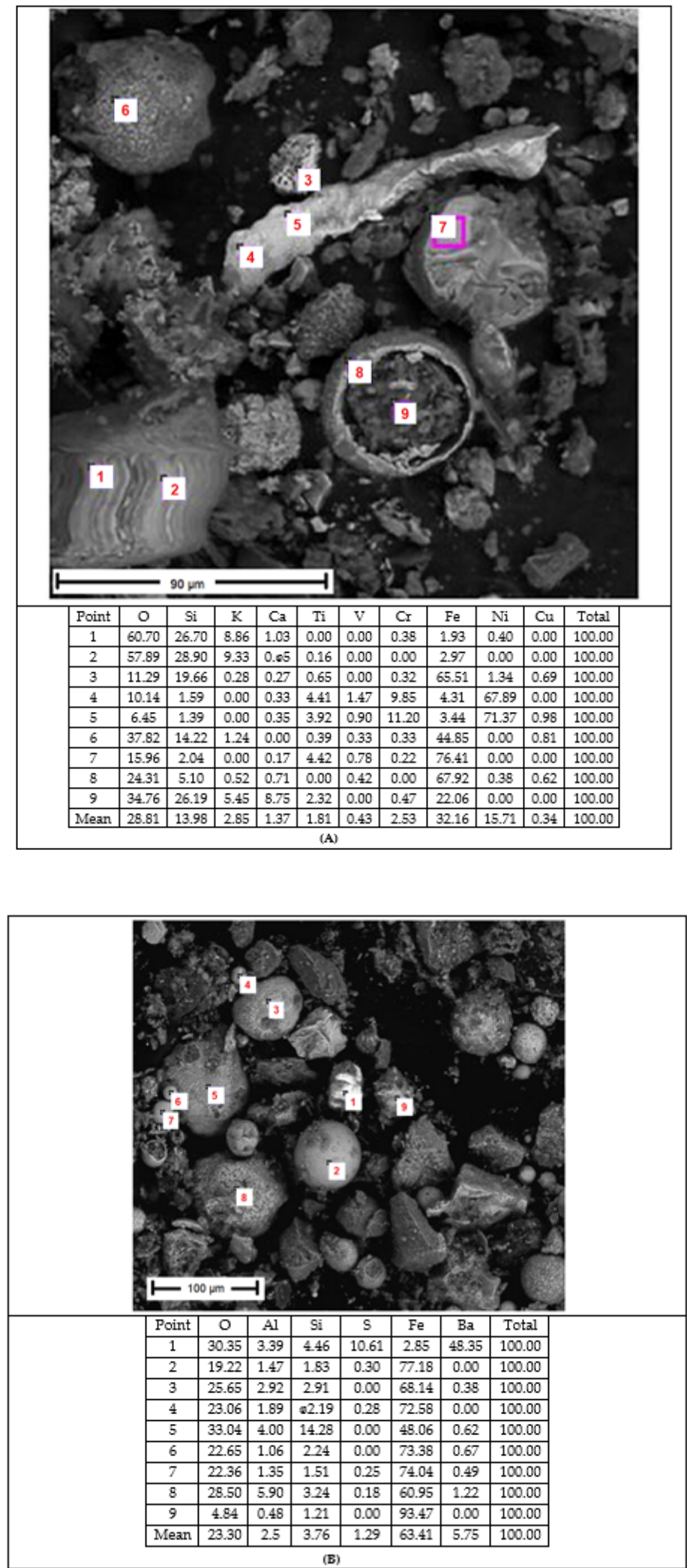

Figure 5. Electron microscopic images, energy dispersive spectrum and chemical composition of particles of the magnetic phase of soils in the city of Gubakha (layer 0-10 cm): (A) residential zone; (B) industrial zone of OAO "Gubakhinsky coke".

The magnetic phase from the $0-10 \mathrm{~cm}$ layer of the Urbic Technosol Loamic, Eutric was composed of the follows minerals: iron-containing silicate (Figure 5A points 1, 2, 6, 9), intermetallic alloy of iron 
(Figure 5A points 4,5), magnetite (Figure 5A point 8), and titanomagnetite (Figure 5A points 3, 7). Among the particles of the magnetic phase of the Urbic Technosol Loamic, Skeletic, the following minerals were identified: barite (Figure 5B point 1 ), magnetite (Figure 5B points $2-4$ and $6-8$ ), wustite (Figure 5B point 9), and iron-containing silicate (Figure 5B point 5).

Spherical magnetic particles contain magnetite, which predominates in the shell of the spherule (Figure 5B point 8). The inner part of some destroyed spherules is filled with particles of iron-containing aluminosilicates (Figure 5A, Figure 6B,E).

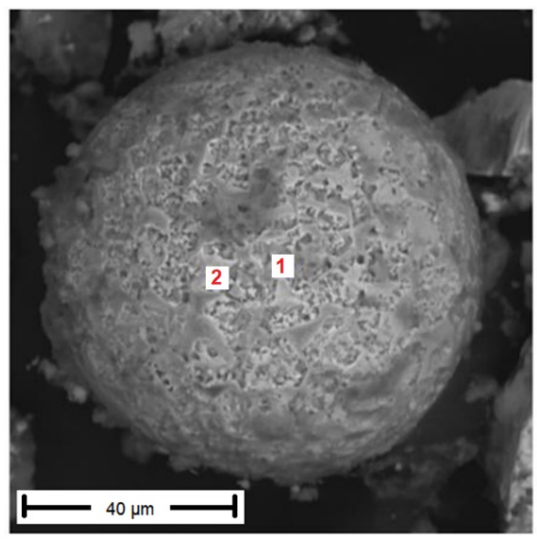

(A)

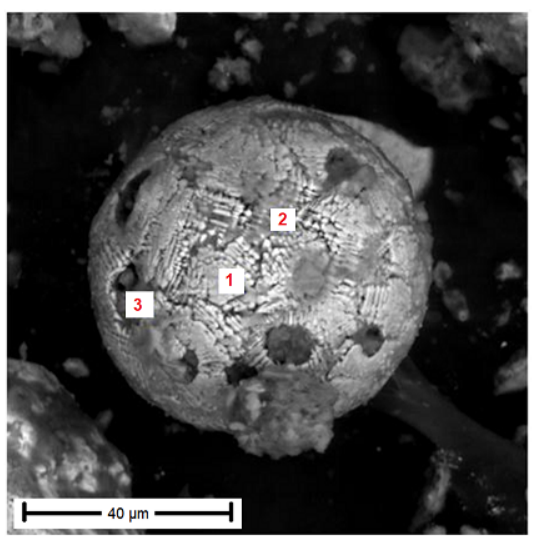

(C)

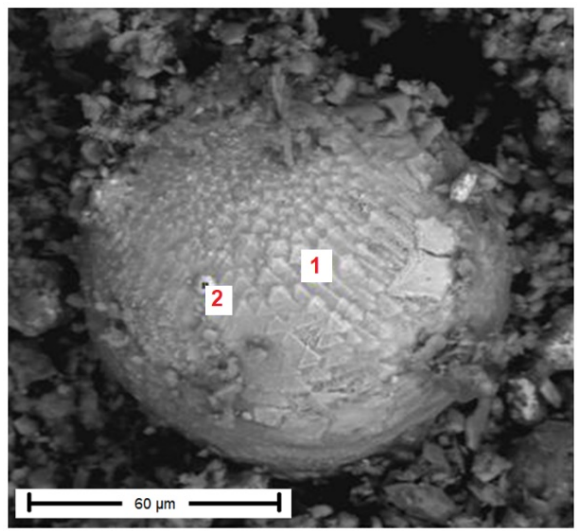

(E)

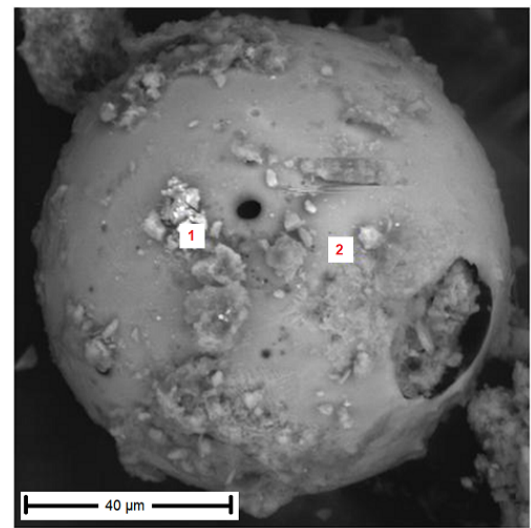

(B)

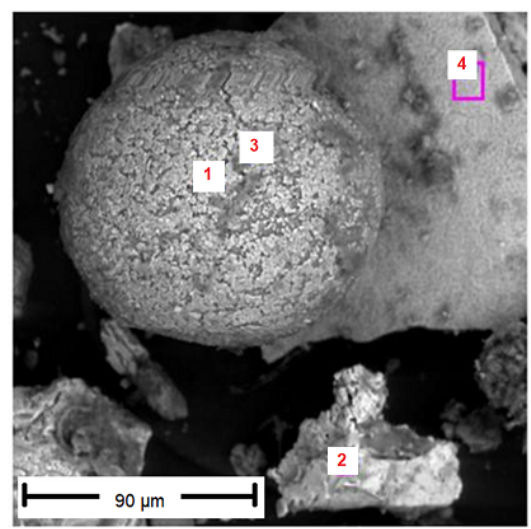

(D)

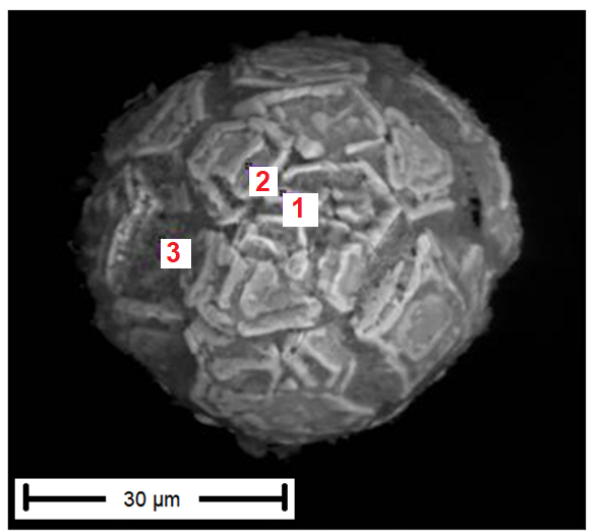

(F)

Figure 6. Cont. 


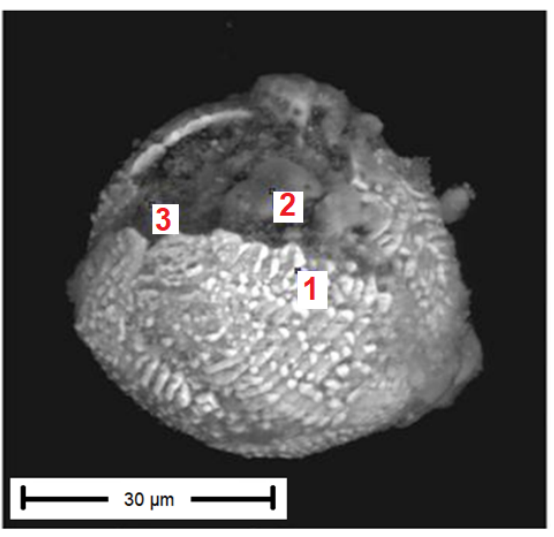

$(\mathbf{G})$

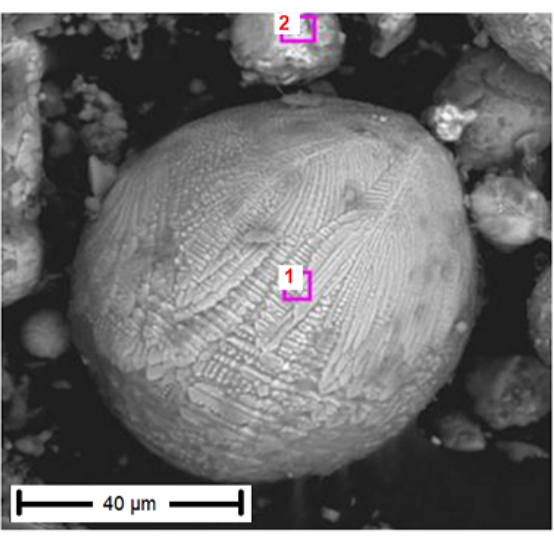

$(\mathbf{H})$

Figure 6. Electron microscopic images of magnetite particles identified by the magnetic phase of the upper soil horizons of Gubakha (layer 0-10 cm): (A-D)—residential zone; (E-H) industrial zone of OAO "Gubakhinsky coke".

Spherules with a rough (Figure 6A) and smooth surface structure (Figure 6B) were encountered in the soils of the residential zone. A particle with a complex surface was revealed (Figure 6C). Some magnetite particles have a detrital shape (Figure 6D point 4). Spherules with an octahedral surface structure (Figure 6D), polygonal with signs of corrosion (Figure 6E) or "astrakhan coating" (Figure 6F) are common in the industrial zone of OAO "Gubakhinsky coke". A magnetite particle with a filamentary surface structure was also identified, on which a new crystal was growing (Figure 6G). Technogenic magnetic spherules with various surface textures have been diagnosed previously by a number of other researchers [59,134-138].

In addition to magnetite spherules, the composition of the magnetic phase of the Urbic Technosol Loamic, Eutric included intermetallic iron alloy (Figure 7A, points 1-2; Figure 7B, points 1-3), wustite (Figure 7A, point 3), titanomagnetite (Figure 7B, point 4), and iron-containing silicate (Figure 7B, point 5).
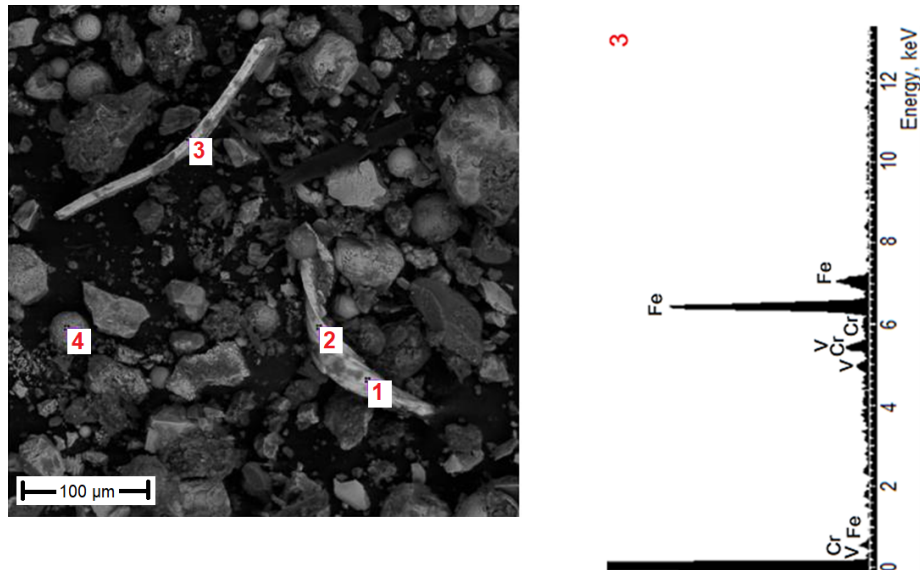

\begin{tabular}{|c|c|c|c|c|c|c|c|}
\hline Point & $\mathrm{O}$ & $\mathrm{Si}$ & $\mathrm{V}$ & $\mathrm{Cr}$ & $\mathrm{Fe}$ & $\mathrm{Ni}$ & Total \\
\hline 1 & 2.87 & 1.50 & 0.59 & 13.38 & 79.59 & 2.07 & 100.00 \\
\hline 2 & 3.61 & 1.85 & 0.52 & 13.40 & 77.19 & 3.44 & 100.00 \\
\hline 3 & 0.00 & 0.43 & 2.68 & 5.08 & 91.81 & 0.00 & 100.00 \\
\hline 4 & 24.06 & 8.56 & 0.00 & 0.00 & 67.38 & 0.00 & 100.00 \\
\hline Mean & 7.63 & 3.09 & 0.95 & 7.96 & 78.99 & 1.38 & 100.00 \\
\hline
\end{tabular}

(A)

Figure 7. Cont. 


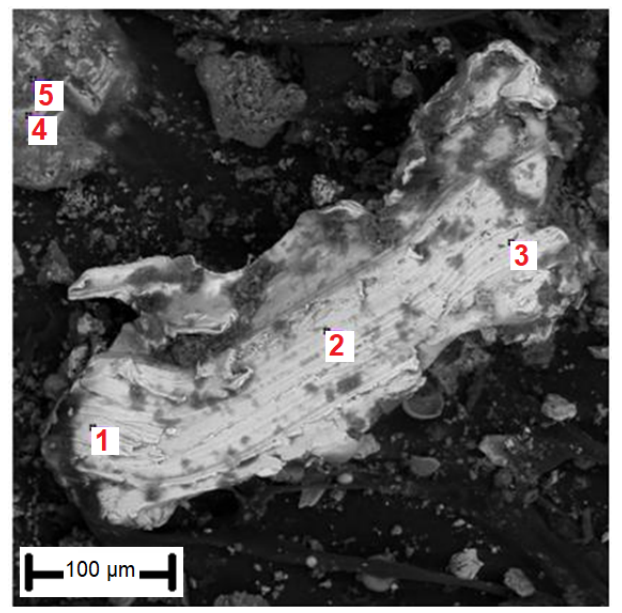

$m$

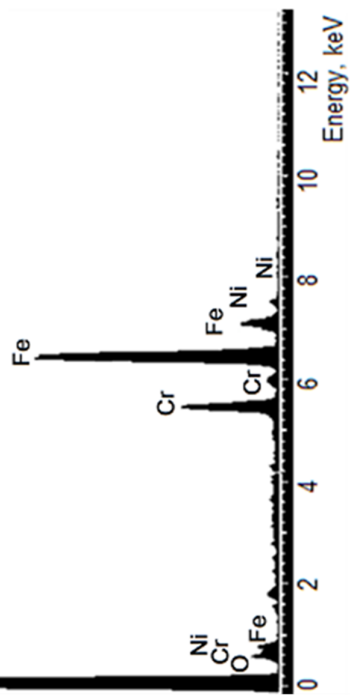

\begin{tabular}{|c|c|c|c|c|c|c|c|c|c|}
\hline Point & $\mathrm{O}$ & $\mathrm{Mg}$ & $\mathrm{Si}$ & $\mathrm{Ca}$ & $\mathrm{Ti}$ & $\mathrm{Cr}$ & $\mathrm{Fe}$ & $\mathrm{Ni}$ & Total \\
\hline 1 & 1.28 & 0.24 & 0.49 & 0.00 & 0.00 & 12.82 & 82.35 & 2.8 & 100.00 \\
\hline 2 & 2.35 & 0.00 & 0.74 & 0.47 & 0.00 & 13.14 & 79.94 & 3.36 & 100.00 \\
\hline 3 & 0.84 & 0.00 & 0.88 & 0.00 & 0.24 & 15.23 & 79.79 & 3.02 & 100.00 \\
\hline 4 & 7.11 & 0.21 & 1.81 & 0.00 & 3.25 & 0.77 & 86.84 & 0.00 & 100.00 \\
\hline 5 & 27.16 & 4.02 & 18.64 & 2.74 & 2.96 & 0.57 & 42.52 & 1.39 & 100.00 \\
\hline Mean & 7.75 & 0.89 & 4.51 & 0.64 & 1.29 & 8.51 & 4.29 & 2.12 & 100.00 \\
\hline
\end{tabular}

(B)
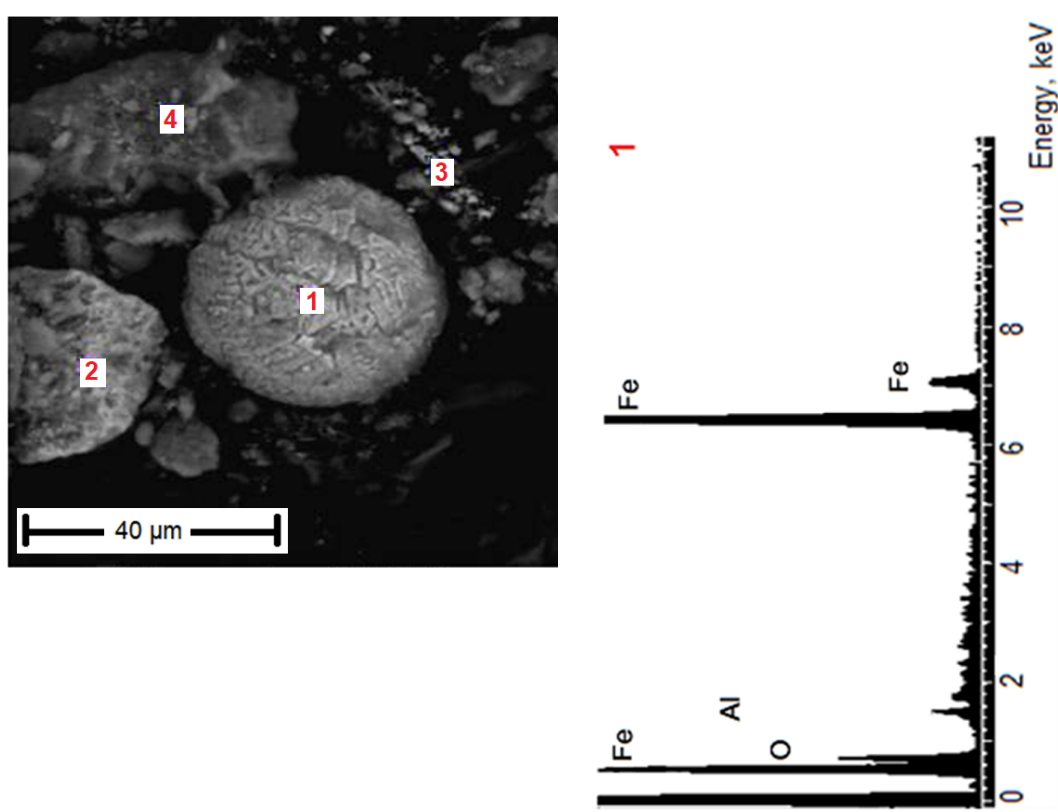

\begin{tabular}{|c|c|c|c|c|c|c|c|c|}
\hline Point & $\mathrm{O}$ & $\mathrm{Al}$ & $\mathrm{Si}$ & $\mathrm{S}$ & $\mathrm{K}$ & $\mathrm{Ti}$ & $\mathrm{Fe}$ & Total \\
\hline 1 & 28.15 & 1.76 & 0.75 & 0.47 & 0.00 & 0.31 & 68.56 & 100.00 \\
\hline 2 & 23.22 & 1.32 & 3.00 & 0.85 & 0.45 & 0.00 & 71.17 & 100.00 \\
\hline 3 & 55.86 & 1.33 & 2.19 & 0.15 & 0.00 & 31.40 & 9.06 & 100.00 \\
\hline 4 & 56.90 & 4.23 & 28.19 & 1.69 & 1.02 & 0.00 & 7.98 & 100.00 \\
\hline Mean & 41.03 & 2.16 & 8.53 & 0.79 & 0.37 & 7.93 & 39.19 & 100.00 \\
\hline
\end{tabular}

(C)

Figure 7. Cont. 

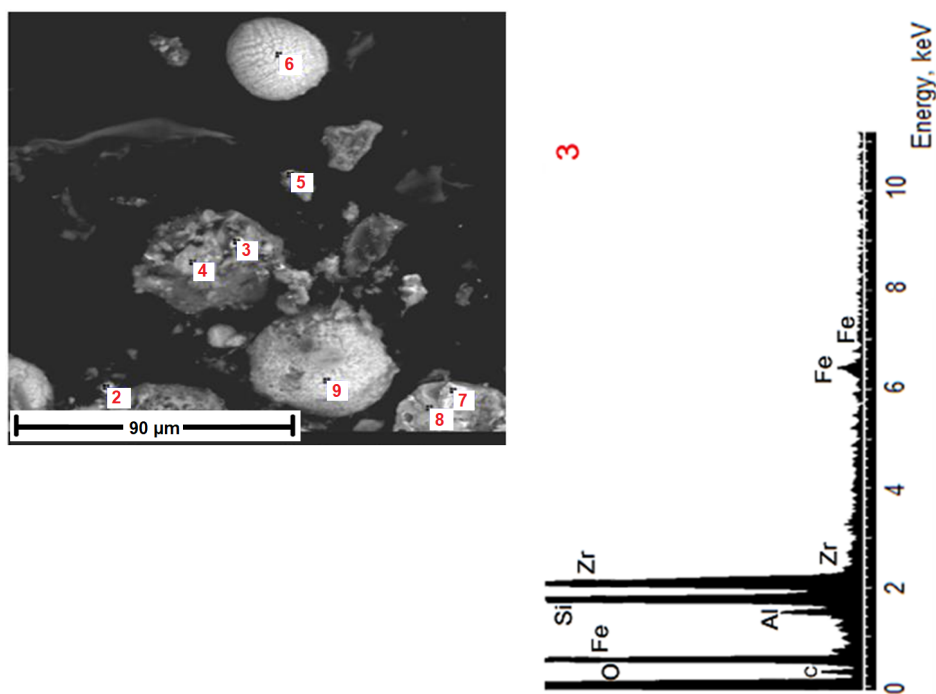

\begin{tabular}{|c|c|c|c|c|c|c|c|c|}
\hline Point & $\mathrm{O}$ & $\mathrm{Al}$ & $\mathrm{Si}$ & $\mathrm{S}$ & $\mathrm{K}$ & $\mathrm{Fe}$ & $\mathrm{Zr}$ & Total \\
\hline 2 & 36.18 & 3.40 & 2.98 & 0.67 & 0.24 & 54.89 & 1.63 & 100.00 \\
\hline 3 & 41.77 & 1.38 & 14.42 & 0.00 & 0.00 & 3.41 & 39.01 & 100.00 \\
\hline 4 & 52.73 & 12.10 & 19.17 & 1.51 & 4.20 & 9.10 & 1.19 & 100.00 \\
\hline 5 & 41.01 & 7.48 & 15.61 & 0.73 & 0.97 & 32.93 & 1.27 & 100.00 \\
\hline 6 & 19.97 & 1.28 & 1.80 & 0.20 & 0.00 & 76.75 & 0.00 & 100.00 \\
\hline 7 & 19.26 & 1.64 & 1.08 & 0.00 & 0.00 & 78.02 & 0.00 & 100.00 \\
\hline 8 & 34.77 & 1.16 & 1.01 & 0.00 & 0.00 & 63.05 & 0.00 & 100.00 \\
\hline 9 & 22.43 & 2.67 & 2.03 & 0.00 & 0.00 & 72.87 & 0.00 & 100.00 \\
\hline Mean & 35.40 & 3.63 & 7.90 & 0.34 & 0.62 & 43.68 & 8.43 & 100.00 \\
\hline
\end{tabular}
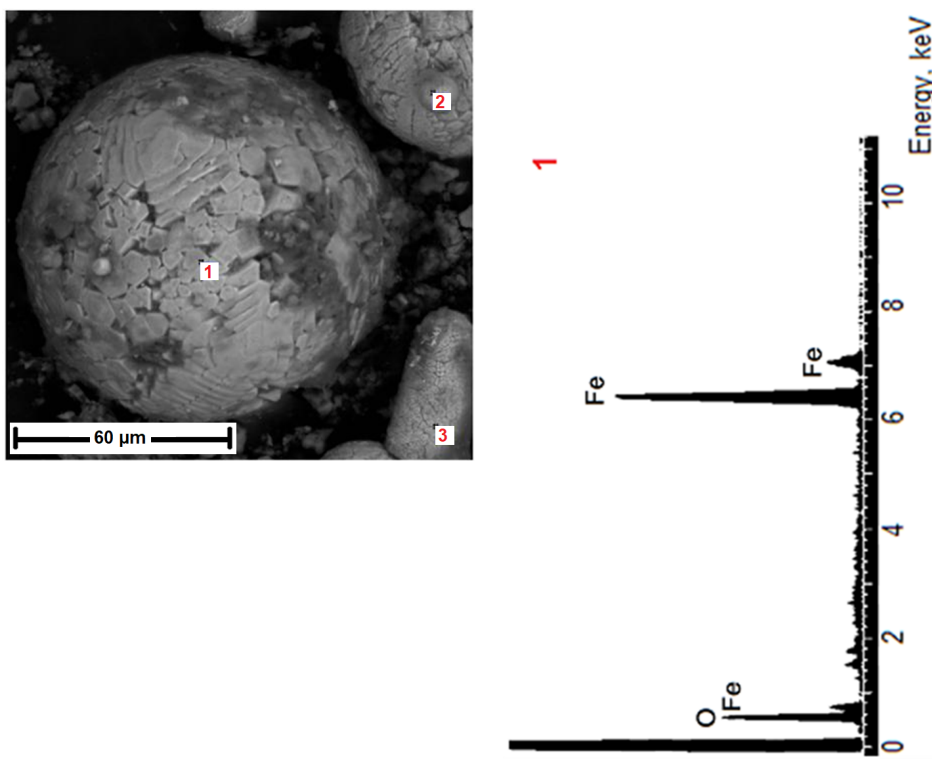

\begin{tabular}{|c|c|c|c|c|}
\hline Point & $\mathrm{O}$ & $\mathrm{Si}$ & $\mathrm{Fe}$ & Total \\
\hline 1 & 19.55 & 1.26 & 79.19 & 100.00 \\
\hline 2 & 27.74 & 3.15 & 69.11 & 100.00 \\
\hline 3 & 13.91 & 1.41 & 84.68 & 100.00 \\
\hline Mean & 20.40 & 1.94 & 77.66 & 100.00 \\
\hline
\end{tabular}

(E)

Figure 7. Electron microscopic images and energy dispersive spectra of particles of the magnetic phase of the upper soil horizons of Gubakha (0-10 cm layer): (A,B)-residential zone; (C-E)—industrial zone of OAO "Gubakhinsky coke". 
In the magnetic phase of the Urbic Technosol Loamic, Skeletic, the following were identified: titanomagnetite (Figure 7C, point 1), rutile (Figure 7C, point 3), iron-containing silicate (Figure 7C, point 4), zircon (Figure 7D, points 1,3), wustite (Figure 7E, point 3) and barite (Figure 7B, point 1).

3.4.4. Mineralogical Composition of the Magnetic Phase according to the Data of Mössbauer Spectroscopy

Figure 8 shows the Mössbauer spectrum of the magnetic phase, with the anomalously high magnetic susceptibility of the soil in the residential zone (subzone D). Table 9 shows its parameters and interpretation. Based on the data on the total iron content and the distribution of iron in individual mineral phases in relative percentage, the quantitative distribution of iron by phases in percentage by weight was also determined. Along with the study of the features of the structure of minerals, Mössbauer spectroscopy makes it possible to judge the features of their elemental chemical composition, and isomorphic substitutions in the lattice.

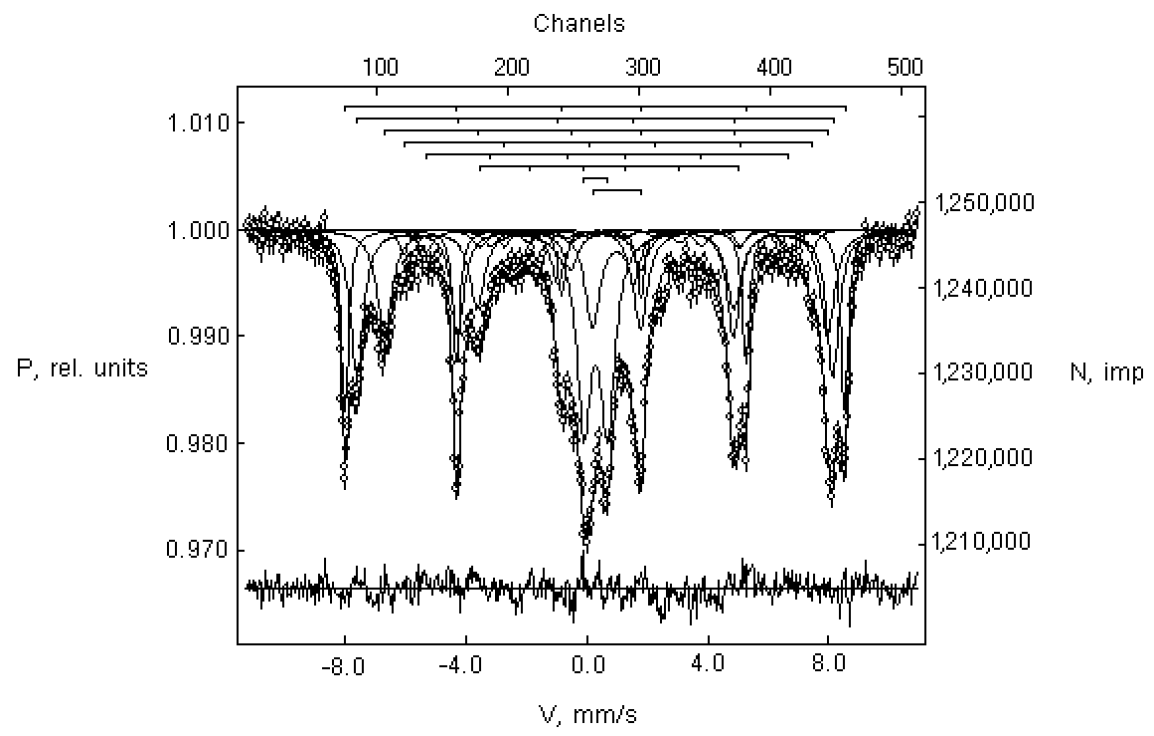

Figure 8. Mössbauer spectrum of the magnetic phase of the upper soil horizon of the Urbic Technosol Loamic, Eutric in the residential part of Gubakha (subzone D).

Table 9. Mössbauer parameters of the sample of the magnetic phase of the upper soil horizon of the Urbic Technosol Loamic, Eutric (subzone D).

\begin{tabular}{|c|c|c|c|c|c|c|c|}
\hline $\begin{array}{l}\text { Spectrum } \\
\text { Component }\end{array}$ & $\begin{array}{c}\text { Isomeric Shift " } \\
\delta, \mathrm{mm} / \mathrm{s}\end{array}$ & $\begin{array}{c}\text { Quadrupole } \\
\text { Splitting } \\
\Delta, \mathrm{mm} / \mathrm{sec}\end{array}$ & $\begin{array}{l}\text { Magnetic Fields } \\
\text { on Nuclei } \mathrm{Fe}^{57} \mathrm{H} \text {, } \\
\text { kOe }\end{array}$ & $\begin{array}{c}\text { Component } \\
\text { Areas } \\
\text { S, \%. }\end{array}$ & $\begin{array}{l}\text { Fe Content in } \\
\text { Samples, } \\
\text { Mass. \% }\end{array}$ & $\begin{array}{c}\text { Fe } \\
\text { Distribution } \\
\text { by Phases, } \\
\text { Mass. \% }\end{array}$ & Interpretation \\
\hline $\mathrm{C} 2\left(\mathrm{Fe}^{3+}\right)$ & 0.29 & -0.02 & 489.0 & 24.9 & \multirow{6}{*}{25.97} & \multirow{3}{*}{13.6} & \multirow{3}{*}{$\begin{array}{c}\text { Magnetite, } \\
\mathrm{S}_{\mathrm{A}} / \mathrm{S}_{\mathrm{B}}=0.91\end{array}$} \\
\hline $\mathrm{C} 3\left(\mathrm{Fe}^{2+}, \mathrm{Fe}^{3+}\right)$ & 0.63 & 0.01 & 455.0 & 20.7 & & & \\
\hline $\mathrm{C} 5\left(\mathrm{Fe}^{2+}, \mathrm{Fe}^{3+}\right)$ & 0.49 & 0.37 & 373.0 & 3.6 & & & \\
\hline $\mathrm{C} 6\left(\mathrm{Fe}^{2+}\right)$ & 0.66 & 0.16 & 266.0 & 3.1 & & 0.8 & Pyrrhotine \\
\hline $\mathrm{D} 1\left(\mathrm{Fe}^{3+}\right)$ & 0.30 & 0.78 & 0 & 17.8 & & 4.6 & Chromite \\
\hline $\mathrm{D} 2\left(\mathrm{Fe}^{2+}\right)$ & 0.99 & 1.58 & 0 & 9.0 & & 2.3 & Chromite \\
\hline
\end{tabular}

The Mössbauer spectrum consists of two doublets (D1, D2) and six sextets (S1-S6). Thus, the sample has paramagnetic and magnetic fractions. As follows from Table 9, the magnetic phase is distinguished by a varied composition of minerals.

Thus, the Mössbauer spectroscopic observations are in complete agreement with the observations obtained by the ESEM and EDS methods. 


\subsubsection{Elemental Chemical Composition of Soil and Magnetic Phases of Soil}

The contents of chemical elements in the soil of the city of Gubakha vary in wide rangesFe 32434-60673 ppm, Mn 32-944 ppm, Cr 90-190 ppm, Ni 35-70 ppm, Cu 14-59 ppm and Zn 70-270 ppm.

In the soil, the maximum values of the total content of Fe 60673, Mn 944 and Cu 59 ppm were noted in the industrial zone of Gubakha (Table 10).

Table 10. Statistical indicators of the content of chemical elements of the upper soil horizons $(0-10 \mathrm{~cm})$ of Gubakha $(p=0.05)$, ppm.

\begin{tabular}{|c|c|c|c|c|c|c|c|}
\hline Sampling Location & Soil Component & $\mathbf{n}$ & $\mathbf{M}$ & $\pm \mathbf{m}$ & Min & Max & $\mathrm{V}, \%$ \\
\hline \multicolumn{8}{|c|}{$\mathrm{Fe}$} \\
\hline \multirow[t]{2}{*}{ Residential zone } & $\begin{array}{c}\text { soil before } \\
\text { magnetic separation }\end{array}$ & 5 & 42,108 & 3193 & 32,993 & 50,118 & 17 \\
\hline & magnetic phase & 5 & 162,489 & 35,023 & 78,288 & 259,748 & 48 \\
\hline \multirow[t]{2}{*}{ Industrial zone } & $\begin{array}{c}\text { soil before } \\
\text { magnetic separation }\end{array}$ & 5 & 45,002 & 6292 & 32,434 & 60,673 & 31 \\
\hline & magnetic phase & 5 & 118,369 & 14,153 & 82,482 & 157,555 & 27 \\
\hline \multicolumn{8}{|c|}{$\mathrm{Mn}$} \\
\hline \multirow[t]{2}{*}{ Residential zone } & $\begin{array}{c}\text { soil before } \\
\text { magnetic separation }\end{array}$ & 5 & 779 & 32 & 681 & 867 & 9 \\
\hline & magnetic phase & 5 & 526 & 75 & 310 & 774 & 32 \\
\hline \multirow[t]{2}{*}{ Industrial zone } & $\begin{array}{c}\text { soil before } \\
\text { magnetic separation }\end{array}$ & 5 & 522 & 166 & 132 & 944 & 71 \\
\hline & magnetic phase & 5 & 619 & 133 & 240 & 998 & 48 \\
\hline \multicolumn{8}{|c|}{$\mathrm{Cr}$} \\
\hline \multirow[t]{2}{*}{ Residential zone } & $\begin{array}{c}\text { soil before } \\
\text { magnetic separation }\end{array}$ & 5 & 136 & 14 & 120 & 190 & 22 \\
\hline & magnetic phase & 5 & 207 & 25 & 145 & 282 & 27 \\
\hline \multirow[t]{2}{*}{ Industrial zone } & $\begin{array}{c}\text { soil before } \\
\text { magnetic separation }\end{array}$ & 5 & 126 & 12 & 90 & 160 & 21 \\
\hline & magnetic phase & 5 & 257 & 38 & 160 & 348 & 33 \\
\hline \multicolumn{8}{|c|}{$\mathrm{Ni}$} \\
\hline \multirow[t]{2}{*}{ Residential zone } & $\begin{array}{c}\text { soil before } \\
\text { magnetic separation }\end{array}$ & 5 & 52 & 6 & 40 & 70 & 25 \\
\hline & magnetic phase & 5 & 100 & 11 & 79 & 138 & 25 \\
\hline \multirow[t]{2}{*}{ Industrial zone } & $\begin{array}{c}\text { soil before } \\
\text { magnetic separation }\end{array}$ & 5 & 49 & 5 & 35 & 57 & 21 \\
\hline & magnetic phase & 5 & 123 & 26 & 67 & 193 & 47 \\
\hline \multicolumn{8}{|c|}{$\mathrm{Cu}$} \\
\hline \multirow[t]{2}{*}{ Residential zone } & $\begin{array}{c}\text { soil before } \\
\text { magnetic separation }\end{array}$ & 5 & 28 & 6 & 14 & 47 & 50 \\
\hline & magnetic phase & 5 & 56 & 6 & 43 & 74 & 25 \\
\hline \multirow[t]{2}{*}{ Industrial zone } & $\begin{array}{c}\text { soil before } \\
\text { magnetic separation }\end{array}$ & 5 & 43 & 7 & 25 & 59 & 36 \\
\hline & magnetic phase & 5 & 92 & 13 & 59 & 127 & 32 \\
\hline \multicolumn{8}{|c|}{$\mathrm{Zn}$} \\
\hline \multirow[t]{2}{*}{ Residential zone } & $\begin{array}{c}\text { soil before } \\
\text { magnetic separation }\end{array}$ & 5 & 130 & 38 & 70 & 270 & 65 \\
\hline & magnetic phase & 5 & 135 & 16 & 99 & 192 & 27 \\
\hline \multirow[t]{2}{*}{ Industrial zone } & $\begin{array}{c}\text { soil before } \\
\text { magnetic separation }\end{array}$ & 5 & 98 & 7 & 80 & 119 & 15 \\
\hline & magnetic phase & 5 & 138 & 8 & 121 & 167 & 13 \\
\hline
\end{tabular}

The highest Cr 190, Ni 70 and Zn 270 ppm were found in the residential zone (Table 10). 


\section{Discussion}

Soil profiles in Gubakha have an eluvial-illuvial type of structure, and a distribution of fine particles with depth. This testifies to the processes of destruction of the mineral part and the movement of silty weathering products (diameter of particles is $<0.001 \mathrm{~mm}$ ) into the underlying horizons under the conditions of the leaching water regime of the foothills of the Middle Urals. The surface AYur,lo horizons contain weakly magnetic anthropogenic inclusions of coal particles and construction waste.

The acidic reaction of the environment contributes to the weathering of TMPs in the soils of the city. The low exchangeable absorption capacity of soils determines the poor resistance of the soils to metal pollution.

The state of the iron-containing phase in the soils of the city of Gubakha, estimated from the analysis of the gross composition and from the data of chemical extraction, is extremely heterogeneous, since the sources of anthropogenic iron in the city are very diverse. The share of non-silicate iron in soils is high (Table 5). Crystallized forms predominate among non-silicate iron minerals. In terms of phase compositions, these are mainly iron oxides, which is also indicated by the high values of the degree of development of oxidogenesis (DO). The accumulation of technogenic iron oxides in the surface horizons of the city soils is confirmed by their abnormally high values of magnetic susceptibility.

The soils of Gubakha are subject to urban ferruginization. The total iron content changes, according to the Yu. N. Vodyanitskiy [132], from medium (4.72\%) to moderately high (16.15\%) (Table 5). Some of the iron compounds have a high $K$.

The contamination with TMPs of the surface soil horizons of Gubakha is diagnosed based on the results of the measurements of the $K$ of soils within different functional zones and subzones of the city. The local background $K$ for the soils of the residential part of the territory of Gubakha is $15 \times 10^{-5}$ SI [139], and for the mountainous territory of the Perm region is $16 \times 10^{-5}$ SI [140]. The average $K$ value of the AYur,lo horizon of the soils of the residential zone exceeds the background values 22 times. The background $K$ is exceeded only nine times in the industrial zone.

The higher $K$ of the soils of the residential zone is associated with their contamination with magnetic particles in the composition of cement dust and vehicle emissions, and the aerial intake of particulate emissions from the Kizelovskaya storage power station, OAO "Gubakhinsky coke". The residential quarters of the city alternate with the territories of industrial enterprises.

The value of $K$ for the soils in the territory adjacent to OAO "Gubakhinsky coke" is non-uniform and varies depending on the geographical location in relation to the source of emissions. The $K$ of soil is slightly higher in the eastward direction from the coke plant than in the southward direction (Table 11), which corresponds to the wind direction in the city (Figure 2B).

Table 11. Evaluation of differences in the magnetic susceptibility of soils in transects in the industrial zone in the area of OAO "Gubakhinsky coke" according to Student's criterion ( $t$ theory $=2.16$ ).

\begin{tabular}{cccccccc}
\hline \multirow{2}{*}{ Direction from the Factory } & $\mathbf{n}$ & \multicolumn{6}{c}{ Comparison Options } \\
\cline { 3 - 8 } & & $\mathbf{1 - 2}$ & $\mathbf{1 - 3}$ & $\mathbf{1 - 4}$ & $\mathbf{2 - 3}$ & $\mathbf{2 - 4}$ & $\mathbf{3 - 4}$ \\
\hline 1 transect (North) & 15 & 1.55 & 1.3 & 1.46 & & & \\
2 transect (East) & 15 & 1.55 & & & 2.21 & 1.71 & \\
3 transect (South) & 15 & & 1.3 & & 2.21 & & 1.71 \\
4 transect (West) & 15 & & & 1.46 & & 1.71 & 1.71 \\
\hline
\end{tabular}

The $K$ of soils of the residential zone is also characterized by high variability, which indicates the effects of several anthropogenic sources of magnets on the soil at once (Table 8). Industrial emissions can have a technogenic impact. The variation of $K$ within the industrial zone of Gubakha is insignificant (9.9\%), since magnetic particles enter the soil from one source-OAO "Gubakhinsky coke".

The values for $K$ in the magnetic phase are determined by the amount of ferrimagnetic magnetite/maghemite, and they are significantly higher than the susceptibility of soil. 
In the magnetic phase of the Urbic Technosol Loamic, Eutric and the Urbic Technosol Loamic, Skeletic of the city of Gubakha, microparticles of various shapes and mineralogical compositions were revealed (Figures 5-7).

Microparticles of various shapes and mineralogical composition were revealed in the magnetic phase of the Urbic Technosol Loamic, Eutric soil and the Urbic Technosol Loamic, Skeletic of the city of Gubakha (Figures 5-7). The magnetic microparticles of soils mainly belong to the minerals of the iron group-magnetite spherules, detrital magnetite, intermetallic iron alloys, titanomagnetite and wustite. Microparticles of rutile, zircon, barite and ferruginous silicates, etc., were also identified in the magnetic phase.

TMPs accumulated in the upper horizons of the urban soils. Magnetic spherules in the soils of Gubakha can accumulate from atmospheric precipitation, which is enriched in magnetite as a result of the high-temperature technological processes of coke production. Thus, in the composition of the magnetic phase of soils of Gubakha, magnetic spherules are widely represented. Previously, E.A. Menshikova and B.M. Osovetsky [59] found that spheres are present in the alluvial sediments in the Kizelovsko-Gubakhinsky industrial district. These spheres are silica-iron, and have a gray or brownish color, a matte sheen, a rough surface, and a relatively large size. They have a lower magnetic susceptibility compared to the group of black spherules. The contents of iron oxides in their chemical composition decrease from 78 to 55 mass\%, respectively, as the contents of $\mathrm{Si}, \mathrm{Al}, \mathrm{Ti}, \mathrm{Ca}, \mathrm{Mg}, \mathrm{Na}, \mathrm{K}$ and Mn increase.

The maximum concentration of spherules was found in the bottom sediments of the Kosva river at a distance of $22 \mathrm{~km}$ downstream of the river from the city of Gubakha, where the coke production is located. According to E.A. Menshikova and B.M. Osovetsky [59], it is the main source of TMPs entering the environment.

Mössbauer analysis of the magnetic phase showed the presence of doublets, which can belong to both finely dispersed Fe oxides and technogenic superparamagnetic hematite. Magnetite has an inverted spinel structure, in which $\mathrm{Fe}^{3+}$ ions are localized in tetrahedral positions at room temperature, and $\mathrm{Fe}^{3+}$ and $\mathrm{Fe}^{2+}$ ions in the octahedral position are bound by electron exchange. The crystallochemical formula of stoichiometric magnetite has the form $\mathrm{Fe}^{3+}\left[\mathrm{Fe}^{3+}, \mathrm{Fe}^{2+}\right] \mathrm{O}_{4}$. The areas in the spectrum of iron ions in the $A$ and $B$ sublattices have a ratio $\left(\mathrm{S}_{\mathrm{A}} / \mathrm{S}_{\mathrm{B}}\right)$ of $1: 2$ or 0.5 .

In the studied sample of the magnetic phase of the Urbic Technosol Loamic, Eutric from Gubakha, the $S_{A} / S_{B}$ ratio in magnetite deviates from 0.5 to a larger disparity, which indicates the presence of isomorphic impurities in the magnetite lattice. The magnetite in the composition of soils in Gubakha is nonstoichiometric. In the studied sample, two additional sextets of Fe ions in the octahedral position are observed. This can be explained by the fact that the particles contain chemical elements from the iron group (chromium, nickel, cobalt, copper, etc.), due to which nonequivalent positions of iron are formed.

A feature of the nonstoichiometric spectra of magnetite is the fact that, in the presence of vacancies, the electronic exchange between $\mathrm{Fe}^{3+}$ and $\mathrm{Fe}^{2+}$ in the octahedral position is disturbed, in which the fraction of $\mathrm{Fe}^{3+}$ not participating in the electronic exchange due to the deficiency of $\mathrm{Fe}^{2+}$ ions contributes to the tetrahedral peak of the Mössbauer spectrum. The reason for the change in the $S_{A} / S_{B}$ ratio in magnetite (isomorphic impurities, or maghemitization) may be the substitution of heavy metal cations for iron cations. It is known that various metals are included in the structure of magnetite/maghemite (ferrite) or hematite by replacing $\mathrm{Fe}^{2+}$ and (or) $\mathrm{Fe}^{3+}$ ions in the crystal lattice [141].

Deciphering the Mössbauer spectrum of the magnetic phase of the Urbic Technosol Loamic, Eutric from Gubakha showed the presence of chromites. Natural Cr-spinels belong to the group of complex oxides $\mathrm{AB}_{2} \mathrm{O}_{4}$, the composition of which is expressed by the formula $\left(\mathrm{Mg}, \mathrm{Fe}^{2+}\right)(\mathrm{Cr}, \mathrm{Al}$, $\left.\mathrm{Fe}^{3+}\right)_{2} \mathrm{O}_{4}$. Chromspilenides are widespread in many types of soils and rocks, with complex chemical compositions and high isomorphic capacity.

A. Hunt et al. [142] and T. Magiera et al. [49] stated that the high concentration of toxic heavy metals in technogenic magnetic particles (TMPs) is explained by the fact that these particles have a low 
stoichiometry and many defects in their crystal lattice, as well as a high isomorphic capacity and a well-developed active surface area.

The pyrrhotite in the magnetic phase was of technogenic origin. T. Magiera [49] pointed out the presence of pyrrhotite in emissions from the by-product coke industry. He found that the magnetic fraction in the composition of the emissions has the form of densely packed aggregates with well-formed crystal structures, a characteristic feature of which was ferromagnetic pyrrhotite.

Soil contamination with HM in the composition of TMPs was revealed by the results of microprobe and energy dispersive analyses of the elemental chemical composition of individual magnetic particles (Figures 5 and 7; Table 12). The concentrations of chemical elements in the soil and in the magnetic phase of the soil differ significantly from each other (Table 10). The magnetic phase of soils is enriched in iron, chromium, nickel, copper and zinc, and contains manganese in smaller quantities. The lower content of manganese in the composition of magnetic particles is explained by the fact that this chemical element is accumulated to a greater extent by the humic substances of the soil, which belong to the diamagnetic part of the soil.

The soils of Gubakha are characterized by an excess of background concentrations and a high variation in the content of $\mathrm{Mn}, \mathrm{Cu}$ and $\mathrm{Zn}$, which indicates the presence of several sources of technogenic pollution containing these elements.

Deciphering the energy dispersive spectra of the particles of the magnetic phase made it possible to establish the features of their elemental chemical composition, and to clarify the mineral phases. The energy dispersive spectrum of the magnetic phase of Urbic Technosol Loamic, Eutric is shown in Figure 9. At some points in the analysis, the iron content varied in the range from 1.5 to $94.3 \%$, and the contents of certain heavy metals reached high values-Co 1.0\%; Ti 31.4; Ti 31.4; V 2.7; Cr 15.2; Ni 71.4; Cu 1; Ba 48.3; Zr 39.0\% (Table 12).

The geochemical series of HM accumulation and dispersion in the surface soil horizons show that heavy metals of the first hazard class (zinc) and the second hazard class (nickel, chromium, copper) [143] have concentration factors $\left(\mathrm{KK}_{\mathrm{B}}, \mathrm{KK}_{\mathrm{A}}\right)$ of more than 1.00 (Figure 10).

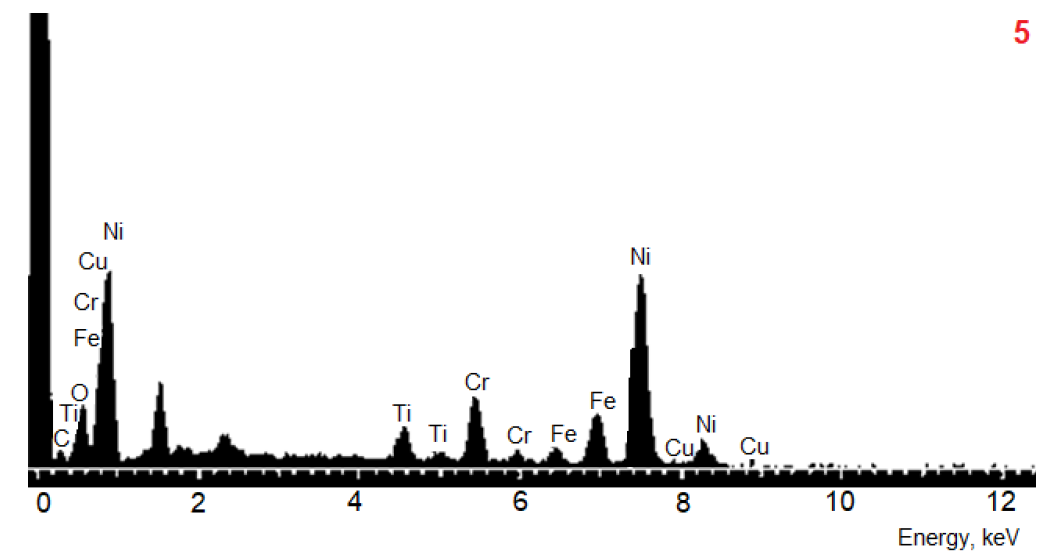

Figure 9. Energy dispersive spectrum of an intermetallic iron alloy from the magnetic phase of the upper soil horizon of the Urbic Technosol Loamic, Eutric in the residential zone of Gubakha (0-10 cm layer). 
Table 12. Chemical composition of magnetic soil particles and phase composition of minerals of magnetic soil particles of the upper soil horizons (0-10 cm) of Gubakha.

\begin{tabular}{|c|c|c|c|c|c|c|c|c|c|c|c|c|}
\hline $\begin{array}{c}\text { The Position of the Energy } \\
\text { Dispersive Analysis Point } \\
\text { in the Figure }\end{array}$ & Sampling Location & $\begin{array}{l}\text { Analysis Point Number } \\
\text { to Which the } \\
\text { Spectrum Corresponds }\end{array}$ & O & $\mathrm{Si}$ & Al & $\mathrm{Fe}$ & $\mathrm{Ca}$ & K & $\mathrm{Mg}$ & Co & $\mathrm{S}$ & Mineral \\
\hline Figure $6 \mathrm{~A}$ & \multirow{4}{*}{$\begin{array}{c}\text { Residential zone } \\
\text { of Gubakha; } \\
\text { Urbic Technosol Loamic, } \\
\text { Eutric }\end{array}$} & $\begin{array}{l}1 \\
2\end{array}$ & $\begin{array}{c}6.60 \\
26.90\end{array}$ & $\begin{array}{c}2.80 \\
10.30\end{array}$ & $\begin{array}{c}13.60 \\
0.00\end{array}$ & $\begin{array}{l}77.00 \\
62.80\end{array}$ & $\begin{array}{l}0.00 \\
0.00\end{array}$ & $\begin{array}{l}0.00 \\
0.00\end{array}$ & $\begin{array}{l}0.00 \\
0.00\end{array}$ & $\begin{array}{l}0.00 \\
0.00\end{array}$ & $\begin{array}{l}0.00 \\
0.00\end{array}$ & $\begin{array}{l}\text { magnetite } \\
\text { magnetite }\end{array}$ \\
\hline Figure 6B & & $\begin{array}{l}1 \\
2\end{array}$ & $\begin{array}{l}31.10 \\
54.70\end{array}$ & $\begin{array}{c}4.10 \\
23.40\end{array}$ & $\begin{array}{l}0.00 \\
0.00\end{array}$ & $\begin{array}{l}63.80 \\
13.80\end{array}$ & $\begin{array}{l}1.00 \\
8.10\end{array}$ & $\begin{array}{l}0.00 \\
0.00\end{array}$ & $\begin{array}{l}0.00 \\
0.00\end{array}$ & $\begin{array}{l}0.00 \\
0.00\end{array}$ & $\begin{array}{l}0.00 \\
0.00\end{array}$ & $\begin{array}{l}\text { silicate-magnetite alloy } \\
\text { silicate-magnetite alloy }\end{array}$ \\
\hline Figure 6C & & $\begin{array}{l}1 \\
2 \\
3\end{array}$ & $\begin{array}{l}33.40 \\
40.80 \\
60.20\end{array}$ & $\begin{array}{l}3.00 \\
16.70 \\
25.50\end{array}$ & $\begin{array}{l}0.00 \\
0.00 \\
0.00\end{array}$ & $\begin{array}{c}61.20 \\
35.50 \\
6.30\end{array}$ & $\begin{array}{l}0.60 \\
2.00 \\
0.70\end{array}$ & $\begin{array}{l}0.00 \\
0.30 \\
3.00\end{array}$ & $\begin{array}{l}1.90 \\
4.70 \\
3.40\end{array}$ & $\begin{array}{l}0.00 \\
0.00 \\
0.00\end{array}$ & $\begin{array}{l}0.00 \\
0.00 \\
0.00\end{array}$ & $\begin{array}{c}\text { magnetite } \\
\text { iron-containing silicate } \\
\text { iron-containing silicate }\end{array}$ \\
\hline Figure 6D & & $\begin{array}{l}1 \\
2 \\
3 \\
4\end{array}$ & $\begin{array}{c}35.90 \\
0.60 \\
44.00 \\
25.50\end{array}$ & $\begin{array}{c}5.80 \\
5.20 \\
18.50 \\
1.10\end{array}$ & $\begin{array}{l}0.00 \\
0.00 \\
0.00 \\
0.00\end{array}$ & $\begin{array}{l}58.10 \\
94.30 \\
34.40 \\
73.40\end{array}$ & $\begin{array}{l}0.30 \\
0.00 \\
2.20 \\
0.00\end{array}$ & $\begin{array}{l}0.00 \\
0.00 \\
0.00 \\
0.00\end{array}$ & $\begin{array}{l}0.00 \\
0.00 \\
0.00 \\
0.00\end{array}$ & $\begin{array}{l}0.00 \\
0.00 \\
1.00 \\
0.00\end{array}$ & $\begin{array}{l}0.00 \\
0.00 \\
0.00 \\
0.00\end{array}$ & $\begin{array}{c}\text { magnetite } \\
\text { wustite } \\
\text { iron-containing silicate } \\
\text { magnetite }\end{array}$ \\
\hline Figure 6E & \multirow{4}{*}{$\begin{array}{l}\text { Industrial zone in the area of } \\
\text { operation of OAO } \\
\text { "Gubakhinsky coke"; Urbic } \\
\text { Technosol Loamic, Skeletic }\end{array}$} & $\begin{array}{l}1 \\
2\end{array}$ & $\begin{array}{l}27.50 \\
30.00\end{array}$ & $\begin{array}{c}14.10 \\
5.00\end{array}$ & $\begin{array}{l}2.70 \\
2.40\end{array}$ & $\begin{array}{l}55.90 \\
62.70\end{array}$ & $\begin{array}{l}0.00 \\
0.00\end{array}$ & $\begin{array}{l}0.00 \\
0.00\end{array}$ & $\begin{array}{l}0.00 \\
0.00\end{array}$ & $\begin{array}{l}0.00 \\
0.00\end{array}$ & $\begin{array}{l}0.00 \\
0.00\end{array}$ & $\begin{array}{l}\text { magnetite } \\
\text { magnetite }\end{array}$ \\
\hline Figure $6 \mathrm{~F}$ & & $\begin{array}{l}1 \\
2 \\
3\end{array}$ & $\begin{array}{l}35.20 \\
39.10 \\
46.30\end{array}$ & $\begin{array}{l}1.00 \\
4.50 \\
11.30\end{array}$ & $\begin{array}{l}1.60 \\
5.10 \\
4.60\end{array}$ & $\begin{array}{l}61.80 \\
50.60 \\
34.70\end{array}$ & $\begin{array}{l}0.00 \\
0.00 \\
0.00\end{array}$ & $\begin{array}{l}0.00 \\
0.00 \\
0.00\end{array}$ & $\begin{array}{l}0.00 \\
0.00 \\
0.00\end{array}$ & $\begin{array}{l}0.00 \\
0.00 \\
0.00\end{array}$ & $\begin{array}{l}0.40 \\
0.70 \\
3.10\end{array}$ & $\begin{array}{c}\text { magnetite } \\
\text { magnetite } \\
\text { iron-containing silicate }\end{array}$ \\
\hline Figure 6G & & $\begin{array}{l}1 \\
2 \\
3\end{array}$ & $\begin{array}{l}21.30 \\
58.20 \\
50.50\end{array}$ & $\begin{array}{l}1.80 \\
36.60 \\
13.30\end{array}$ & $\begin{array}{l}1.80 \\
2.50 \\
7.50\end{array}$ & $\begin{array}{l}74.70 \\
1.50 \\
22.70\end{array}$ & $\begin{array}{l}0.00 \\
1.00 \\
1.80\end{array}$ & $\begin{array}{l}0.00 \\
0.00 \\
0.00\end{array}$ & $\begin{array}{l}0.00 \\
0.00 \\
0.00\end{array}$ & $\begin{array}{l}0.00 \\
0.00 \\
0.00\end{array}$ & $\begin{array}{l}0.40 \\
0.20 \\
4.10\end{array}$ & $\begin{array}{l}\text { magnetite } \\
\text { iron-containing silicate } \\
\text { iron-containing silicate }\end{array}$ \\
\hline Figure $6 \mathrm{H}$ & & $\begin{array}{l}1 \\
2\end{array}$ & $\begin{array}{l}28.60 \\
24.80\end{array}$ & $\begin{array}{l}7.60 \\
4.00\end{array}$ & $\begin{array}{l}5.30 \\
2.10\end{array}$ & $\begin{array}{l}58.50 \\
69.10\end{array}$ & $\begin{array}{l}0.00 \\
0.00\end{array}$ & $\begin{array}{l}0.00 \\
0.00\end{array}$ & $\begin{array}{l}0.00 \\
0.00\end{array}$ & $\begin{array}{l}0.00 \\
0.00\end{array}$ & $\begin{array}{l}0.00 \\
0.00\end{array}$ & $\begin{array}{l}\text { magnetite } \\
\text { magnetite }\end{array}$ \\
\hline
\end{tabular}


In the industrial zone, the magnetic phase of the soil is enriched in $\mathrm{Fe}, \mathrm{Ni}, \mathrm{Cu}, \mathrm{Cr}, \mathrm{Zn}$ and $\mathrm{Mn}$, and in the magnetic particles of the soils of the residential zone, the accumulation of $\mathrm{Fe}, \mathrm{Cu}, \mathrm{Ni}$ and $\mathrm{Cr}$ is observed (Figure 10A).

The geochemical series of the accumulation-dispersion of chemical elements in the soil of Gubakha are shown in the Figure 10B-D:

$\mathrm{I}_{\text {geo }}$ Fe $6.3<\mathrm{Cu} 1.1=\mathrm{Ni} 1.1<\mathrm{Zn} 1.0=\mathrm{Cr} 1.0<\mathrm{Mn} 0.7$;

$\mathrm{KK}_{\mathrm{B}}$ (background) Fe $59.7<\mathrm{Cu} 2.0<\mathrm{Ni} 1.7<\mathrm{Zn} 1.6<\mathrm{Cr} 1.5<\mathrm{Mn} 0.8$;

$\mathrm{KK}_{\mathrm{A}}$ (by V.A. Alekseenko) Fe $2.0<\mathrm{Cr} 1.6<\mathrm{Ni} 1.5<\mathrm{Cu} 0.9=\mathrm{Mn} 0.9<\mathrm{Zn} 0.7$.

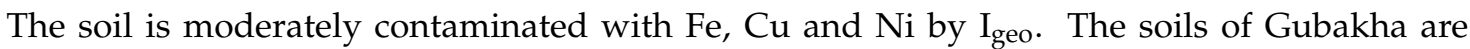
contaminated with $\mathrm{Fe}, \mathrm{Cu}, \mathrm{Ni}, \mathrm{Zn}$ and $\mathrm{Cr}$ relative to the background soil $\left(\mathrm{KK}_{\mathrm{B}}\right)$, and with $\mathrm{Fe}, \mathrm{Cr}$, and $\mathrm{Ni}$ relative to the clarke of the soils of residential landscapes, according to V.A. Alekseenko $\left(\mathrm{KK}_{\mathrm{A}}\right)$.

The PLIs of the soils in the residential and industrial zones are 2.6, and the total for Gubakha is 2.7. The PLI indicates the high contamination level of the soils of Gubakha (Figure 10E).

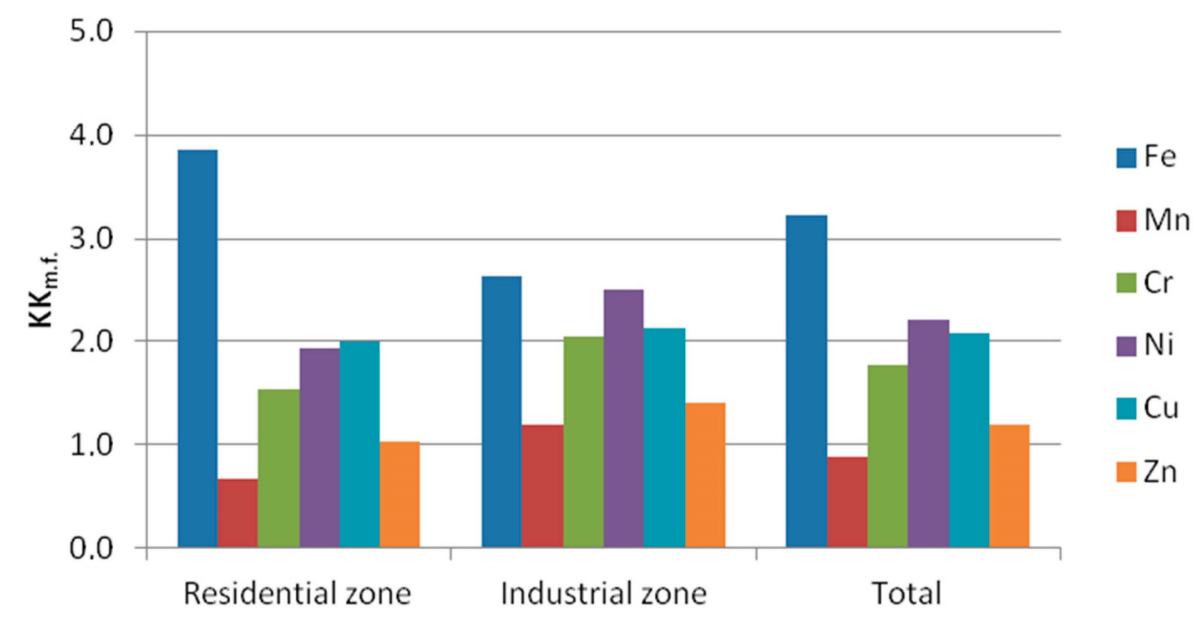

(A)

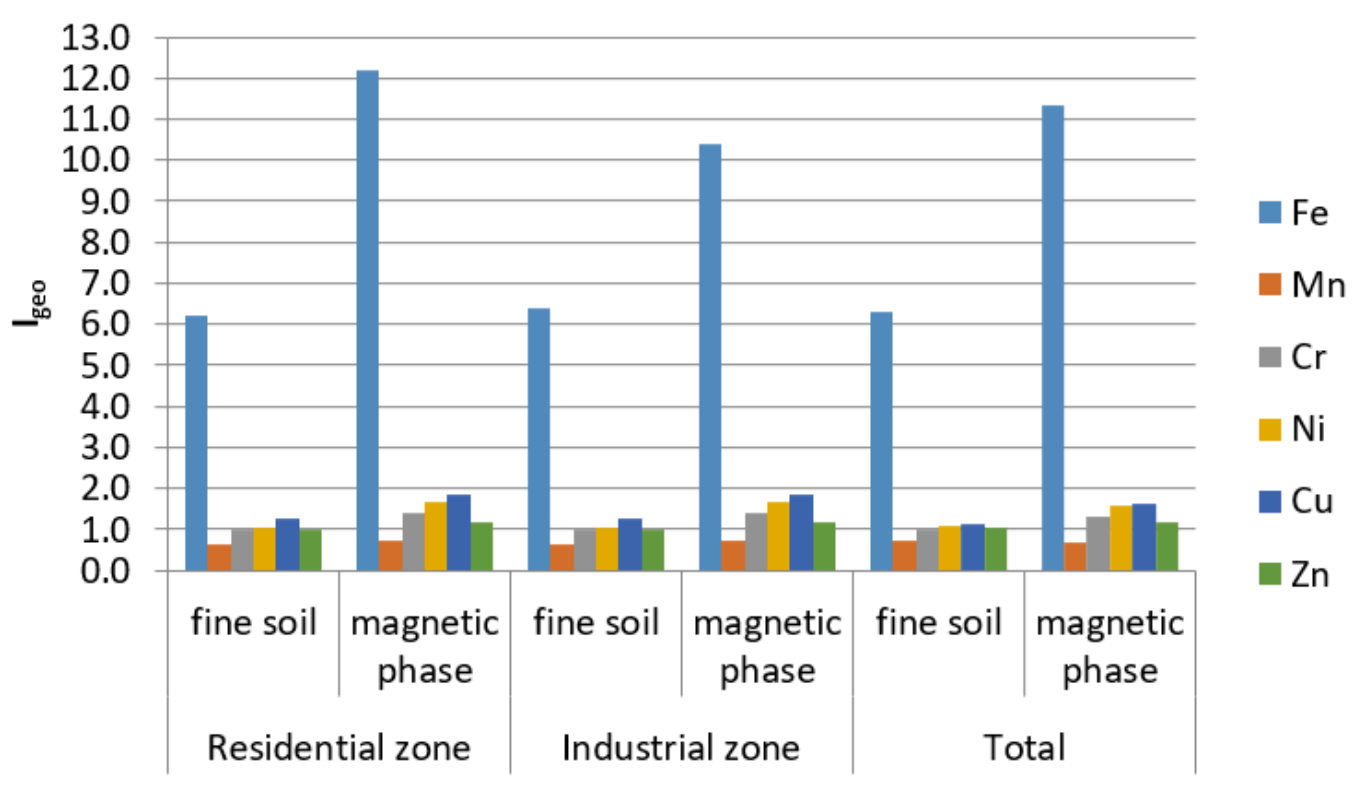

(B)

Figure 10. Cont. 


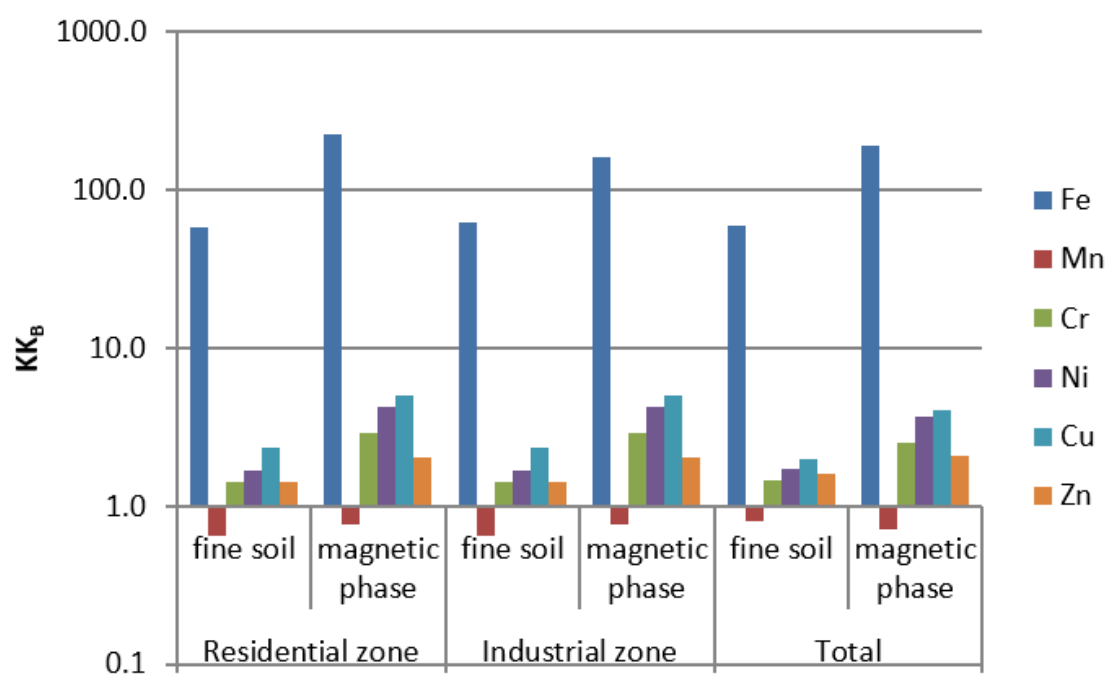

(C)

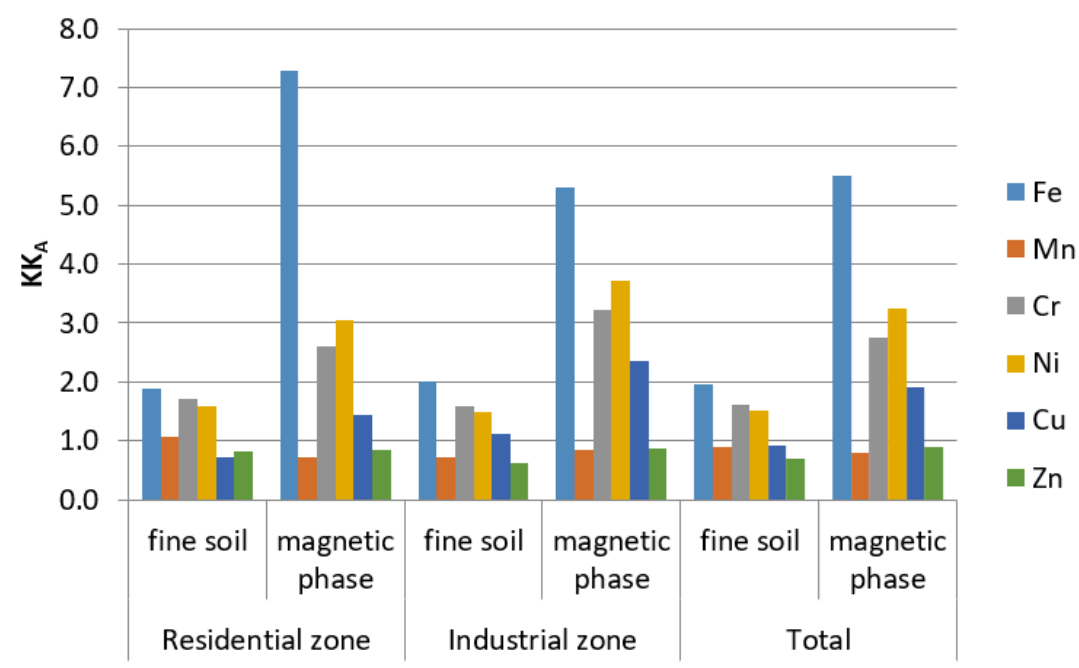

(D)

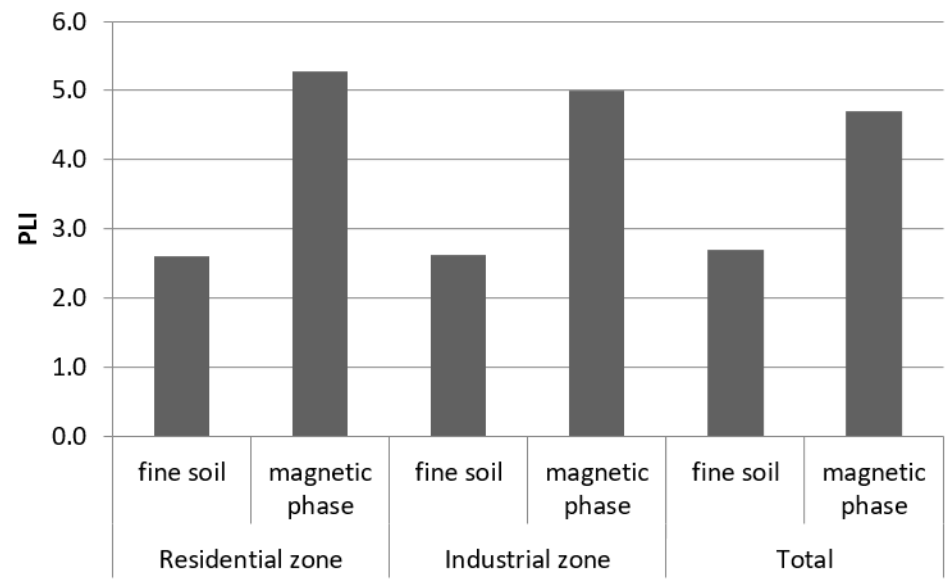

(E)

Figure 10. Geochemical sequences for soils of Gubakha: (A) Coefficient of enrichment of the magnetic phase in heavy metals, $\mathrm{KK}_{\text {m.f. }}$ (B) Geo-accumulation Index, $\mathrm{I}_{\text {geo }}$; (C) Coefficient of concentration relative to the background, $\mathrm{KK}_{\mathrm{B}}$; (D) Coefficient of concentration relative to the clarke of soils of residential landscapes in Russia according to V.A. Alekseenko, $\mathrm{KK}_{\mathrm{A}}$; (E) Pollution load index, PLI. 
Paired correlation analyses of $K$ and the contents of chemical elements in the soils of the city of Gubakha showed the strong relationship of $K$ with Fe, $\mathrm{Cr}$ and Ni (Tables 13 and 14). An association of Fe with $\mathrm{Cr}$, as well as with $\mathrm{Ni}$, was found. These connections are due to the fact that $\mathrm{Fe}, \mathrm{Cr}$ and $\mathrm{Ni}$ are part of the highly magnetic minerals of the spinel group. A strong bond has been established between $\mathrm{Ni}$ and $\mathrm{Cu}$.

Table 13. Correlation matrix of magnetic susceptibility and the contents of chemical elements in the soils of the residential zone of Gubakha, $n=10, p=0.05$.

\begin{tabular}{ccccccc}
\hline & $\boldsymbol{K}$ & $\mathbf{F e}$ & $\mathbf{M n}$ & $\mathbf{C r}$ & $\mathbf{N i}$ & $\mathbf{C u}$ \\
\hline $\mathrm{Fe}$ & 0.71 & & & & & \\
$\mathrm{Mn}$ & -0.33 & -0.62 & & & & \\
$\mathrm{Cr}$ & 0.70 & 0.78 & -0.39 & & & \\
$\mathrm{Ni}$ & 0.71 & 0.91 & -0.71 & 0.67 & & \\
$\mathrm{Cu}$ & 0.51 & 0.63 & -0.76 & 0.30 & 0.81 & \\
$\mathrm{Zn}$ & -0.15 & -0.02 & -0.40 & -0.24 & 0.22 & 0.47 \\
\hline
\end{tabular}

Table 14. Correlation matrix of magnetic susceptibility and the content of chemical elements in the soils of the industrial zone in the area of OAO "Gubakhinsky coke", $n=10, p=0.05$.

\begin{tabular}{ccccccc}
\hline & $\boldsymbol{K}$ & $\mathbf{F e}$ & $\mathbf{M n}$ & $\mathbf{C r}$ & $\mathbf{N i}$ & $\mathbf{C u}$ \\
\hline $\mathrm{Fe}$ & 0.85 & & & & & \\
$\mathrm{Mn}$ & 0.23 & -0.09 & & & & \\
$\mathrm{Cr}$ & 0.81 & 0.75 & 0.46 & & & \\
$\mathrm{Ni}$ & 0.69 & 0.94 & -0.11 & 0.73 & & \\
$\mathrm{Cu}$ & 0.75 & 0.97 & -0.12 & 0.69 & 0.95 & \\
$\mathrm{Zn}$ & 0.77 & 0.89 & -0.35 & 0.50 & 0.81 & 0.82 \\
\hline
\end{tabular}

The sources of HM in the composition of TMPs in the soils of Gubakha can be coke production, the operation of a thermal power plant, transport emissions, and construction waste. It is not possible to distinguish the individual impacts of individual sources on the chemical composition of the soils of the city.

The analysis of the composition of iron compounds in soils is most often used to characterize the processes of soil formation and soil fertility [131,144]. The average iron content in the world's soils is $3.8 \%$ [136]. It was also found that iron compounds, along with organic matter, affect the soil's ability to absorb HM [85]. Depending on acid-base and redox conditions, iron can be present in the soil in oxidation states $\mathrm{Fe}^{3+}$ and $\mathrm{Fe}^{2+}$.

In the magnetic phase of the soil of the Urbic Technosol Loamic, Eutric and the Urbic Technosol Loamic, Skeletic of Gubakha, microparticles of various shapes and mineralogical composition were revealed (Figure 5). The magnetic microparticles of soils mainly belong to the minerals of the iron group -intermetallic iron alloys, detrital magnetite, magnetite spherules, titanomagnetite and wustite. Microparticles of rutile, zircon, barite and iron-containing silicates, etc., were also identified in the magnetic phase.

The studied particles of the magnetic phase are dominated by iron oxides and iron-containing silicates (Figure 6). The iron content in the composition of magnetic inclusions is more than $60 \%$, i.e., exceeds the clarke value by almost 16 -fold.

The contamination of soils with HM, confirmed by the high values of the volumetric magnetic susceptibility, was also revealed by a microprobe study of the elemental chemical compositions of some magnetic particles (Figures 6 and 7).

Spherical magnetite particles accumulate in the upper soil horizons as a result of their aerial pollution. Magnetic spherules in the soils of Gubakha can accumulate from atmospheric precipitation, which is enriched in spherical magnetite as a result of the high-temperature technological processes of coke production (Figure 5). 
Microprobe and energy dispersive analyses revealed the accumulation of iron, barium, zircon, manganese and titanium in the magnetic phase isolated from the Urbic Technosol Loamic, Skeletic of the industrial zone. The amount of other chemical elements considered in the work, with a high atomic mass (chromium, copper, nickel, zinc) in the magnetic phase, is less than $0.1 \%$, which does not allow them to be reliably diagnosed by the method of energy dispersive analysis.

Thus, the microprobe diagnostics of the magnetic phase of the Urbic Technosol Loamic, Eutric of the residential zone of Gubakha reflect the technogenic origin of the minerals that enter the soils of the city by air. The composition of magnetic particles in soils is diverse-intermetallic iron alloys, detrital magnetite, magnetite spherules, titanomagnetite, and wustite. Magnetic iron-bearing minerals of technogenic origin contain nickel, chromium, cobalt, manganese and other HM as impurities.

\section{Conclusions}

The soils of the city Gubakha are subject to urban ferruginization. The total iron content in the soils of the city reaches $16.15 \%$. For the first time, the features of the manifestation of technogenic oxidogenesis and the accumulation of TMPs in soils in the urban area of the Middle Urals have been characterized. The mineralogical and elemental chemical composition of the highly magnetic soils of the city Gubakha has been determined and characterized.

It has been established that the magnetic susceptibility of the surface soil horizons exceeds the background values 22-fold for the territory of the residential zone, and 9-fold for the industrial zone of Gubakha. The composition of the magnetic particles in the soils is diverse-magnetite spherules, detrital magnetite, intermetallic iron alloys, titanomagnetite and wustite. TMPs accumulate in the upper soil horizons. Magnetic spherules in the soils of Gubakha can accumulate as a result of atmospheric precipitation, which is enriched in magnetite as a result of the high-temperature technological processes of coke-chemical production. The physicochemical properties of the soils of the city determine the resistance to the weathering of magnetite. The acidic reaction of the environment contributes to the weathering of TMPs in the soils of the city. The low exchangeable absorption capacity of soils determines the poor resistance of soils to metal pollution. The soil profiles have an eluvial-illuvial structure, and conditions are created for the influx of metals into groundwater.

Mössbauer spectroscopy showed that the magnetite in the magnetic phase is nonstoichiometric. Magnetic iron-containing minerals contain nickel, chromium, cobalt, manganese and other heavy metals as impurities. The soil is moderately contaminated with $\mathrm{Fe} 6-12, \mathrm{Cu} 1.1$, and $\mathrm{Ni} \mathrm{1.1}$, as determined by $\mathrm{I}_{\text {geo }}$. The pollution load index (PLI) values of soils in the residential and industrial zones were both 2.6, which indicates the high contamination level of the soils of Gubakha.

The combination of methods for measuring magnetic susceptibility, and determining the mineralogical composition of iron compounds and elemental chemical composition, has shown the effectiveness of this approach when conducting an ecological-geochemical assessment of the soil cover of the city of Gubakha. The administration of Gubakha should pay attention to the advisability of monitoring the elemental chemical composition of the city's soils, including using the methods of ecological magnetism, to identify the areas of soils contaminated with nickel and chromium and make environmental decisions.

The surface soil horizons of the city of Gubakha are enriched in $\mathrm{Zn}, \mathrm{Cu}, \mathrm{Ni}$ and $\mathrm{Cr}$, as well as in magnetic iron compounds. The magnetic susceptibility of the surface soil horizons in the residential and industrial zones of the city exceeds the background values, by 22- and 9-fold, respectively. The magnetic phase of the soils is diverse in morphology and mineralogical and elemental chemical composition, consisting of spherical, acute-angled particles of magnetite, maghemite, hematite, pyrrhotite, intermetallic alloys, chrome-spelinide, and others. The sources of man-made magnetic particles in soils in the territory of Gubakha could be coke production, thermal power plants, motor vehicles and construction materials (cement). The magnetic phase of the city's soils is enriched with $\mathrm{Cr}, \mathrm{Ni}, \mathrm{Co}, \mathrm{Ti}, \mathrm{V}, \mathrm{Cu}, \mathrm{Zr}$ and $\mathrm{Ba}$, which pose a potential threat to the life and health of the population. The soil is moderately contaminated Fe 6-12, Cu 1.1 and Ni 1.1, as determined by $\mathrm{I}_{\text {geo }}$. 
The pollution load index (PLI) values of the soils in the residential and industrial zones were both 2.6, which indicated the high contamination level of the soils of Gubakha. The complex use of the methods of magnetism and elemental chemical composition has shown the effectiveness of this approach in carrying out the ecological-geochemical assessment of the soils of the city of Gubakha.

Author Contributions: Conceptualization, A.V.; methodology, A.V.; field work, S.G. and M.R.; software, S.G. and M.R.; validation, S.G. and M.R.; formal analysis, A.V., S.G. and M.R.; investigation, A.V.; data analysis, A.V.; writing-original draft preparation, A.V. and M.R.; writing-review and editing, A.V.; visualization, A.V., S.G. and M.R. All authors have read and agreed to the published version of the manuscript.

Funding: The reported study was funded by Russian Foundation for Basic Research, project number 19-34-90070 "Assessment and measures to reduce the environmental risks of soil contamination with heavy metals in the composition of magnetic particles in the management of agricultural enterprises in areas with a high level of anthropogenic pressure on the environment and soil cover".

Acknowledgments: The authors are grateful to geol.-mineral. Sciences V.V. Korovushkin, National Research Technological University "Moscow Institute of Steel and Alloys" (MISiS) for conducting Mössbauer spectroscopy; Candidate of Biological Sciences V.G. Dvurechensky, Institute of Soil Science and Agrochemistry of the Siberian Branch of the Russian Academy of Sciences for the determination the forms of iron; Candidate of Physical and Mathematical Sciences V.A. Tselmovich, Borok Geophysical Observatory of the Branch of the Institute of Physics of the Earth named after O. Yu. Shmidt RAS for performing microprobe and energy dispersive analyses; Candidate of Technical Sciences I.A. Roshchina, Vernadsky Institute of Geochemistry and Analytical Chemistry of Russian Academy of Sciences for the determination of the elemental chemical composition; Candidate of Biological Sciences A.N. Chashin, Perm State Agro-Technological University for advice on mapping; students E. Gette and E. Baranova, Perm State Agro-Technological University for help in the selection of soil samples; and the Russian Foundation for Basic Research for supporting research work. The authors are grateful to the anonymous reviewers of the manuscript for their valuable comments and suggestions that contributed to its improvement.

Conflicts of Interest: The authors declare no conflict of interest.

\section{References}

1. Strzyszcz, Z.; Magiera, T.; Heller, F. The influence of industrial immissions on the magnetic susceptibility of soils in Upper Silesia. Studia Geophys. Geod. 1996, 40, 276-286. [CrossRef]

2. Schmidt, A.; Yarnold, R.; Hill, M.; Ashmore, M. Magnetic susceptibility as proxy for heavy metal pollution: A site study. J. Geochem. Explor. 2005, 85, 109-117. [CrossRef]

3. Bortnikova, S.B.; Raputa, V.F.; Devyatova, A.Y.; Yudakhin, F.N. Methods of data analysis of snow cover pollution in the zones of influence of industrial enterprises (for example, Novosibirsk). Geoecol. Eng. Geol. Hydrogeol. Geocryol. 2009, 6, 515-525. (In Russian)

4. Evdokimova, G.; Kalabin, G.; Mozgova, N. Contents and toxicity of heavy metals in soils of the zone affected by aerial emissions from the Severonikel Enterprise. Eurasian Soil Sci. 2011, 44, 237-244. [CrossRef]

5. Chikeneva, I. Consequences of the impact of heavy metals on the environment in the zone of impact of industrial enterprises. Sci. Method Electr. Mag. Concept 2013, 12, 66-70. (In Russian)

6. Bi, C.; Chen, Y.; Zhao, Z.; Li, Q.; Zhou, Q.; Ye, Z.; Ge, X. Characteristics, sources and health risks of toxic species (PCDD/Fs, PAHs and heavy metals) in PM2. 5 during fall and winter in an industrial area. Chemosphere 2020, 238, 124620. [CrossRef] [PubMed]

7. Jiang, Y.; Ma, J.; Ruan, X.; Chen, X. Compound health risk assessment of cumulative heavy metal exposure: A case study of a village near a battery factory in Henan Province, China. Environ. Sci. Process. Impacts 2020, 22, 1408-1422. [CrossRef]

8. Tang, J.; He, M.; Luo, Q.; Adeel, M.; Jiao, F. Heavy Metals in Agricultural Soils from a Typical Mining City in China: Spatial Distribution, Source Apportionment, and Health Risk Assessment. Polish J. Environ. Stud. 2020, 29, 1379-1390. [CrossRef]

9. Kim, W.; Doh, S.-J.; Park, Y.-H.; Yun, S.-T. Two-year magnetic monitoring in conjunction with geochemical and electron microscopic data of roadside dust in Seoul, Korea. Atmos. Environ. 2007, 41, 7627-7641. [CrossRef]

10. Ignatenko, O.V.; Mescherova, N.A. Assessment of snow cover pollution by heavy metals in the residential area of Bratsk. In Proceedings of the II Scientific and Practical Conference with International Participation Ecological and Biological Problems of Siberia and Adjacent Territories, Nizhnevartovsk, Russia, 30 March 2011; pp. 236-239. (In Russian). 
11. Sorokina, O.I.; Kosheleva, N.E.; Kasimov, N.S.; Golovanov, D.L.; Bazha, S.N.; Dorzhgotov, D.; Enkh-Amgalan, S. Heavy metals in the air and snow cover of Ulan Bator. Geogr. Nat. Resour. 2013, 3, 159-170. (In Russian) [CrossRef]

12. Medvedev, I.F.; Derevyagin, S.S. Heavy Metals in Ecosystems; Rakurs: Saratov, Russia, 2017; p. 178. (In Russian)

13. Lee, P.-K.; Kang, M.-J.; Yu, S.; Kwon, Y.K. Assessment of trace metal pollution in roof dusts and soils near a large Zn smelter. Sci. Total Environ. 2020, 713, 136536. [CrossRef]

14. Li, J.; Wang, G.; Liu, F.; Cui, L.; Jiao, Y. Source Apportionment and Ecological-Health Risks Assessment of Heavy Metals in Topsoil Near a Factory, Central China. Expo. Health 2020. [CrossRef]

15. Shamsaddin, H.; Jafari, A.; Jalali, V.; Schulin, R. Spatial distribution of copper and other elements in the soils around the Sarcheshmeh copper smelter in southeastern Iran. Atmos. Pollut. Res. 2020,11,1681-1691. [CrossRef]

16. Fedorova, A.I.; Shunelko, E.V. Contamination of the surface soil horizons of Voronezh with heavy metals. VSU Bulletin. Ser. Geogr. Geoecol. 2003, 1, 74-82. (In Russian)

17. Taati, A.; Salehi, M.H.; Mohammadi, J.; Mohajer, R.; Díez, S. Pollution assessment and spatial distribution of trace elements in soils of Arak industrial area, Iran: Implications for human health. Environ. Res. 2020, 187, 109577. [CrossRef]

18. Xu, Z.; Mi, W.; Mi, N.; Fan, X.; Zhou, Y.; Tian, Y. Characteristics and sources of heavy metal pollution in desert steppe soil related to transportation and industrial activities. Environ. Sci. Pollut. Res. 2020, 27, 38835-38848. [CrossRef]

19. Yakovlev, E.Y.; Zykova, E.N.; Zykov, S.B.; Malkov, A.V.; Bazhenov, A.V. Heavy metals and radionuclides distribution and environmental risk assessment in soils of the Severodvinsk industrial district, NW Russia. Environ. Earth Sci. 2020, 79, 215-233. [CrossRef]

20. Zhou, Y.; Wang, L.; Xiao, T.; Chen, Y.; Beiyuan, J.; She, J.; Zhou, Y.; Yin, M.; Liu, J.; Liu, Y. Legacy of multiple heavy metal (loid) s contamination and ecological risks in farmland soils from a historical artisanal zinc smelting area. Sci. Total Environ. 2020, 720, 137541. [CrossRef]

21. Bourliva, A.; Kantiranis, N.; Papadopoulou, L.; Aidona, E.; Christophoridis, C.; Kollias, P.; Evgenakis, M.; Fytianos, K. Seasonal and spatial variations of magnetic susceptibility and potentially toxic elements (PTEs) in road dusts of Thessaloniki city, Greece: A one-year monitoring period. Sci. Total Environ. 2018, 639, 417-427. [CrossRef] [PubMed]

22. Vladimirov, S.N.; Skorik, A.S. The influence of motor transport and industry on the content of heavy metals in the soils of Tula. Actual Dir. Sci. Res. XXI Century Theory Pract. 2014, 2, 332-335. (In Russian)

23. Fang, H.; Gui, H.; Yu, H.; Li, J.; Wang, M.; Jiang, Y.; Wang, C.; Chen, C. Characteristics and source identification of heavy metals in abandoned coal-mining soil: A case study of Zhuxianzhuang coal mine in Huaibei coalfield (Anhui, China). Hum. Ecol. Risk Assess. Int. J. 2020, 1-16. [CrossRef]

24. Laniyan, T.A.; Adewumi, A.J. Evaluation of Contamination and Ecological Risk of Heavy Metals Associated with Cement Production in Ewekoro, Southwest Nigeria. J. Health Pollut. 2020, 10, 200306. [CrossRef]

25. Eluyera, I.M.; Tukura, B.W. Assessment of Heavy Metals in Soil and Vegetables Grown around some Automobile Workshops in Federal Capital Territory Abuja, Nigeria. Chem. Res. J. 2020, 5, 162-173.

26. Kapička, A.; Petrovský, E.; Ustjak, S.; Macháčková, K. Proxy mapping of fly-ash pollution of soils around a coal-burning power plant: A case study in the Czech Republic. J. Geochem. Explor. 1999, 66, 291-297. [CrossRef]

27. Matveenko, T.I.; Molchanova, M.A.; Terenina, I.B. Heavy metals in the soil cover of the zone of influence of CHPP-3. Bull. Pac. State Univ. 2008, 1, 223-230. (In Russian)

28. Sharma, A.P.; Tripathi, B. Magnetic mapping of fly-ash pollution and heavy metals from soil samples around a point source in a dry tropical environment. Environ. Monit. Assess. 2008, 138, 31-39. [CrossRef]

29. Osipova, N.; Yazikov, E.; Tarasova, N.; Osipov, K. Heavy metals in soils in the areas affected by coal enterprises and their impact on public health. Bezop. Tekhnosfere Saf. Techno Sphere 2015, 2, 16-26. [CrossRef]

30. Derbentseva, A.M.; Popova, E.A.; Brikmans, A.V.; Cherentsova, A.A.; Mayorova, L.P.; Matveenko, T.I. The ecological state of the territory of the Shtykovskaya technogenic-industrial system. Sib. Ecol. J. 2016, 23, 793-804. [CrossRef]

31. Medunić, G.; Kuharić, Ž.; Krivohlavek, A.; Đuroković, M.; Dropučić, K.; Rađenović, A.; Lužar Oberiter, B.; Krizmanić, A.; Bajramović, M. Selenium, sulphur, trace metal, and BTEX levels in soil, water, and lettuce from the Croatian Raša Bay contaminated by superhigh-organic-sulphur coal. Geosciences 2018, 8, 408. [CrossRef] 
32. Krylov, D.A. Heavy metals in thermal power plant fly ash. Energy Econ. Technol. Ecol. 2010, 4, 44-50. (In Russian)

33. Bilguun, U.; Namkhainyambuu, D.; Purevsuren, B.; Soyol-Erdene, T.-O.; Tuuguu, E.; Daichaa, D. Sources, Enrichment, and Geochemical Fractions of Soil Trace Metals in Ulaanbaatar, Mongolia. Arch. Environ. Contam. Toxicol. 2020, 79, 219-232. [CrossRef]

34. Prokhorova, N.V. Biogeochemical effect of automobile transport in urban environment conditions. Samara State Univ. Bull. 2005, 5, 188-199. (In Russian)

35. Adimalla, N.; Chen, J.; Qian, H. Spatial characteristics of heavy metal contamination and potential human health risk assessment of urban soils: A case study from an urban region of South India. Ecotoxicol. Environ. Saf. 2020, 194, 110406. [CrossRef] [PubMed]

36. Akintunde, E.A.; Ore, O.T.; Durodola, S.S.; Sharaibi, J.E.; Adegbite, O.B. Contamination Assessment of Potentially Toxic Metals in Road-Side Surface Soils Along Iwo-Ibadan Expressway, Nigeria. Surf. Sci. 2020, 5, 1-5. [CrossRef]

37. Bartkowiak, A. The accumulation of selected heavy metals in soils in the vicinity of a busy road. Soil Sci. Annu. 2020, 71, 118-124. [CrossRef]

38. Dogra, N.; Sharma, M.; Sharma, A.; Keshavarzi, A.; Kaur, M.; Bhardwaj, R.; Thukral, A.K.; Kumar, V. Pollution assessment and spatial distribution of roadside agricultural soils: A case study from India. Int. J. Environ. Health Res. 2020, 30, 146-159. [CrossRef]

39. Chen, J.; Li, T.; Wang, L. Soil Heavy Metal Pollution in the soil of Railway Traffic: A Mini-review. Acad. J. Agric. Life Sci. 2020, 1, 1-8. [CrossRef]

40. Kazimov, M.A.; Geyushova, N.D.; Alieva, N.V. Comparative assessment of the anthropogenic load of heavy metals on the environment of urban agglomeration. Biomedicine 2019, 2, 22-28. (In Russian)

41. Sazonova, O.V.; Ryazanova, T.K.; Tupikova, D.S.; Sudakova, T.V.; Toropova, N.M.; Vistyak, L.N. Comparative characteristics of anthropogenic pollution of the snow cover of the territory of a large industrial center under the influence of various sources of pollution. Popul. Health Environ. 2019, 3, 36-42. (In Russian)

42. Rolka, E.; Zolnowski, A.C.; Kozlowska, K.A. Assessment of the content of trace elements in soils and roadside vegetation in the vicinity of some gasoline stations in Olsztyn (Poland). J. Elem. 2020, 25, 549-563. [CrossRef]

43. Rolka, E.; Żołnowski, A.C.; Sadowska, M.M. Assessment of Heavy Metal Content in Soils Adjacent to the DK16-Route in Olsztyn (North-Eastern Poland). Pol. J. Environ. Stud. 2020, 29, 4303-4311. [CrossRef]

44. Seghier, T.B.; Bouhadjera, K. Pollution Assessment of Heavy Metals in Roadside Agricultural Soils. Pol. J. Environ. Stud. 2020, 29, 2855-2863. [CrossRef]

45. P Rakhmatov, M.N.; Maslov, V.A.; Abdullaev, S.F. Distribution dynamics of heavy metals and arsenic in dust aerosol and soils of Northern Tajikistan. Chem. Saf. 2019, 3, 78-93. (In Russian)

46. Acar, R.U.; Özkul, C. Investigation of heavy metal pollution in roadside soils and road dusts along the Kütahya-Eskişehir Highway. Arab. J. Geosci. 2020, 13, 1-11. [CrossRef]

47. Szwalec, A.; Mundała, P.; Kędzior, R.; Pawlik, J. Monitoring and assessment of cadmium, lead, zinc and copper concentrations in arable roadside soils in terms of different traffic conditions. Environ. Monit. Assess. 2020, 192, 155. [CrossRef]

48. Ladonin, D.V.; Mikhailova, A.P. Heavy metals and arsenic in soils and street dust of the South-Eastern administrative district of Moscow: Results of long-term research. Pochvovedenie 2020, 11, 1401-1411. (In Russian)

49. Magiera, T.; Jabłońska, M.; Strzyszcz, Z.; Rachwal, M. Morphological and mineralogical forms of technogenic magnetic particles in industrial dusts. Atmos. Environ. 2011, 45, 4281-4290. [CrossRef]

50. Bourliva, A.; Papadopoulou, L.; Aidona, E.; Giouri, K.; Simeonidis, K.; Vourlias, G. Characterization and geochemistry of technogenic magnetic particles (TMPs) in contaminated industrial soils: Assessing health risk via ingestion. Geoderma 2017, 295, 86-97. [CrossRef]

51. Dekkers, M.; Pietersen, H.S. Magnetic properties of low-Ca fly ash: A rapid tool for Fe-assessment and a survey for potentially hazardous elements. MRS Online Proc. Libr. Arch. 1992, 245, 37-47. [CrossRef]

52. Magiera, T.; Gołuchowska, B.; Jabłońska, M. Technogenic magnetic particles in alkaline dusts from power and cement plants. Water Air Soil Pollut. 2013, 224, 1389. [CrossRef]

53. Zhu, Z.; Li, Z.; Bi, X.; Han, Z.; Yu, G. Response of magnetic properties to heavy metal pollution in dust from three industrial cities in China. J. Hazard. Mater. 2013, 246, 189-198. [CrossRef] [PubMed]

54. Vodyanitskii, Y.N. Natural and technogenic compounds of heavy metals in soils. Eurasian Soil Sci. 2014, 47, 255-265. [CrossRef] 
55. Rachwał, M.; Magiera, T.; Wawer, M. Coke industry and steel metallurgy as the source of soil contamination by technogenic magnetic particles, heavy metals and polycyclic aromatic hydrocarbons. Chemosphere 2015, 138, 863-873. [CrossRef]

56. Wawer, M.; Magiera, T.; Ojha, G.; Appel, E.; Kusza, G.; Hu, S.; Basavaiah, N. Traffic-related pollutants in roadside soils of different countries in Europe and Asia. Water Air Soil Pollut. 2015, 226, 216. [CrossRef]

57. Lu, S.; Yu, X.; Chen, Y. Magnetic properties, microstructure and mineralogical phases of technogenic magnetic particles (TMPs) in urban soils: Their source identification and environmental implications. Sci. Total Environ. 2016, 543, 239-247. [CrossRef]

58. Szuszkiewicz, M.M.; Łukasik, A.; Magiera, T.; Szuszkiewicz, M. Technogenic magnetic particles of topsoil from different sources of emission-A case study from upper silesian conurbation, Poland. In Proceedings of the Fire and Environmental Safety Engineering 2018 (FESE 2018); EDP Sciences: Les Ulis, France, 2018; Volume 247, p. 7.

59. Menshikova, E.A.; Osovetsky, B.M. Magnetic spherules of natural and technogenic sediments. Mod. Probl. Sci. Educ. 2015, 1, 1829. (In Russian)

60. Yu, X.; Lu, S. Multiscale correlations of iron phases and heavy metals in technogenic magnetic particles from contaminated soils. Environ. Pollut. 2016, 219, 19-27. [CrossRef]

61. Hulett, L.; Weinberger, A.; Northcutt, K.; Ferguson, M. Chemical species in fly ash from coal-burning power plants. Science 1980, 210, 1356-1358. [CrossRef] [PubMed]

62. Hansen, L.D.; Silberman, D.; Fisher, G.L. Crystalline components of stack-collected, size-fractionated coal fly ash. Environ. Sci. Technol. 1981, 15, 1057-1062. [CrossRef]

63. Vassilev, S.V.; Vassileva, C.G.; Karayigit, A.I.; Bulut, Y.; Alastuey, A.; Querol, X. Phase-mineral and chemical composition of composite samples from feed coals, bottom ashes and fly ashes at the Soma power station, Turkey. Int. J. Coal Geol. 2005, 61, 35-63. [CrossRef]

64. Yazikov, E.G.; Talovskaya, A.V.; Zhornyak, L.V. Assessment of the Ecological and Geochemical State of the Territory of Tomsk according to the Study of Dust Aerosols and Soils; Publishing House of the Tomsk Polytechnic University: Tomsk, Russia, 2010; p. 264. (In Russian)

65. Blaha, U.; Sapkota, B.; Appel, E.; Stanjek, H.; Rösler, W. Micro-scale grain-size analysis and magnetic properties of coal-fired power plant fly ash and its relevance for environmental magnetic pollution studies. Atmos. Environ. 2008, 42, 8359-8370. [CrossRef]

66. Babanin, V.; Trukhin, V.; Karpachevskii, L.; Ivanov, A.; Morozov, V. Soil Magnetism; YAGTU: Yaroslavl, Russia, 1995; p. 223. (In Russian)

67. Dearing, J.A.; Hay, K.L.; Baban, S.M.J.; Huddleston, A.S.; Wellington, E.M.H.; Loveland, P.J. Magnetic susceptibility of soil: An evaluation of conflicting theories using a national data set. Geophys. J. Int. 1996, 127, 728-734. [CrossRef]

68. Maher, B.A. Magnetic properties of modern soils and Quaternary loessic paleosols: Paleoclimatic implications. Palaeogeogr. Palaeoclimatol. Palaeoecol. 1998, 137, 25-54. [CrossRef]

69. Strzyszcz, Z. Ferromagnetic properties of forest soils being under influence of industrial pollution. In Air Pollution and Forest Decline; Eidgenössische Anstalt für das Forstliche Versuchswesen: Birmensdorf, Switzerland, 1989; pp. 201-207.

70. Strzyszcz, Z. Magnetic susceptibility of soils in the areas influenced by industrial emissions. In Soil Monitoring; Springer: Berlin/Heidelberg, Germany, 1993; pp. 255-269.

71. Georgeaud, V.M.; Rochette, P.; Ambrosi, J.P.; Vandamme, D.; Williamson, D. Relationship between heavy metals and magnetic properties in a large polluted catchment: The Etang de Berre (South of France). Phys. Chem. Earth 1997, 22, 211-214. [CrossRef]

72. Strzyszcz, Z.; Magiera, T. Magnetic susceptibility and heavy metals contamination in soils of southern Poland. Phys. Chem. Earth 1998, 23, 1127-1131. [CrossRef]

73. Petrovský, E.; Kapička, A.; Jordanova, N.; Knab, M.; Hoffmann, V. Low-field magnetic susceptibility: A proxy method of estimating increased pollution of different environmental systems. Environ. Geol. 2000, 39, 312-318. [CrossRef]

74. Wang, X.S.; Yong, Q. Correlation between magnetic susceptibility and heavy metals in urban topsoil: A case study from the city of Xuzhou, China. Environ. Geol. 2005, 49, 10-18. [CrossRef]

75. Matysek, D.; Raclavska, H.; Raclavsky, K. Correlation between magnetic susceptibility and heavy metal concentrations in forest soils of the eastern Czech Republic. J. Environ. Eng. Geophys. 2008, 13, 13-26. [CrossRef] 
76. Hanesch, M.; Scholger, R. Mapping of heavy metal loadings in soils by means of magnetic susceptibility measurements. Environ. Geol. 2002, 42, 857-870.

77. Kapper, K.L.; Bautista, F.; Goguitchaishvili, A.; Bógalo, M.F.; Cejudo-Ruíz, R.; Cervantes Solano, M. The use and misuse of magnetic methods to monitor environmental pollution in urban areas. Boletín Soc. Geológica Mex. 2020, 72,1-44. [CrossRef]

78. Czarnowska, K. Total content of heavy metals in parent rocks as reference background levels of soils. Soil Sci. Annu. 1996, 47, 43-50.

79. Martín, J.A.R.; Arias, M.L.; Corbí, J.M.G. Heavy metals contents in agricultural topsoils in the Ebro basin (Spain). Application of the multivariate geoestatistical methods to study spatial variations. Environ. Pollut. 2006, 144, 1001-1012. [CrossRef]

80. Micó, C.; Recatalá, L.; Peris, M.; Sánchez, J. Assessing heavy metal sources in agricultural soils of an European Mediterranean area by multivariate analysis. Chemosphere 2006, 65, 863-872. [CrossRef]

81. Sulima, A.F.; Levshakov, L.V. A method for assessing local soil contamination with heavy metals. Bull. Kursk State Agric. Acad. 2008, 4, 10-12. (In Russian)

82. Levshakov, L.V. Rationing of the content of heavy metals in the soil. Bull. Kursk State Agric. Acad. 2011, 3,51-53. (In Russian)

83. Anda, M. Cation imbalance and heavy metal content of seven Indonesian soils as affected by elemental compositions of parent rocks. Geoderma 2012, 189, 388-396. [CrossRef]

84. Ladonin, D. The effect of iron and clay minerals on the adsorption of copper, zinc, lead, and cadmium in the nodular horizon of podzolic soil. Eurasian Soil Sci. 2003, 36, 1065-1073.

85. Karpukhin, M.; Ladonin, D. Effect of soil components on the adsorption of heavy metals under technogenic contamination. Eurasian Soil Sci. 2008, 41, 1228-1237. [CrossRef]

86. Ouyang, J.; Liu, Z.; Zhang, L.; Wang, Y.; Zhou, L. Analysis of influencing factors of heavy metals pollution in farmland-rice system around a uranium tailings dam. Process Safety Environ. Prot. 2020, 139, 124-132. [CrossRef]

87. Romzaykina, O.N.; Vasenev, V.I.; Paltseva, A.; Kuzyakov, Y.V.; Neaman, A.; Dovletyarova, E.A. Assessing and mapping urban soils as geochemical barriers for contamination by heavy metal (loid) $\mathrm{s}$ in Moscow megapolis. J. Environ. Qual. 2020, 1-16. [CrossRef]

88. Eremchenko, O.Z.; Shestakov, I.E.; Moskvina, N.V. Soils and Technogenic Surface Formations of Urbanized Territories of the Perm Kama Region; Perm State National Research University: Perm, Russia, 2016; p. 252. (In Russian)

89. Eremchenko, O.Z.; Moskvina, N.V. The properties of soils and technogenic surface formations in the multistory districts of Perm city. Eurasian Soil Sci. 2005, 38, 688-694. (In Russian)

90. Vasiliev, A.A.; Chashchin, A.N. Heavy Metals in the Soils of the City of Chusovoy: Assessment and Diagnostics of Pollution; Prokrost: Perm, Russia, 2011; p. 197. (In Russian)

91. Vasiliev, A.A.; Lobanova, E.S. Magnetic and Geochemical Assessment of the Soil Cover of the Urbanized Territories of the Urals on the Example of the City of Perm; Prokrost: Perm, Russia, 2015; p. 243. (In Russian)

92. Kopylov, I.S. Ecological and geochemical patterns and anomalies of trace element content in soils and snow cover of the Urals and the city of Perm. Perm Univ. Bulletin. Geol. 2012, 4, 39-46. (In Russian)

93. Kopylov, I.S. Anomalies of heavy metals in soils and snow cover of the city of Perm as manifestations of factors of geodynamics and technogenesis. Basic Res. 2013, 2, 335-339. (In Russian)

94. Shishkin, M.A.; Lapteva, A.K. Ecological and Geochemical Analysis of Modern Landscapes of the Kama Region; IEGM UB RAS: Perm, Russia, 2009; p. 335.

95. May, I.V.; Vekovshinina, S.A.; Babina, S.V.; Balashov, S.Y. Quantitative assessment of correlations between exposure and the content of contaminants in biological media of children with chronic inflammatory gastroduodenal diseases. Fam. Health 21st Century 2010, 2, 4. (In Russian)

96. Zaitseva, N.V.; May, I.V. Regional experience of taking into account indicators of risk to public health in spatial planning tasks. Ars Adm. 2011, 2, 30-39. (In Russian)

97. Shiryaeva, I.A.; Popova, E.V. Heavy metals in drinking water on geochemical provinces in the Perm region as factors. Perm Univ. Bull. Ser. Biol. 2014, 4, 89-96. (In Russian) 
98. Toropov, L.I.; Fotina, I.V. Determination of the content of heavy metals in the hair of the adult population of Perm. In Proceedings of the International Scientific-Practical Conference; OOO “Marker": Vologda, Russia, 2017; pp. 6-7.

99. Dolgikh, O.V.; Starkov, K.G.; Alikina, I.N.; Chelakova, Y.A.; Guselnikov, M.A.; Nikonoshin, N.A.; Krivtsov, A.V.; Mazunin, A.A. Peculiarities of immune regulation and genetic polymorphism in urban population exposed to heavy metals. Perm Univ. Bull. Ser. Biol. 2019, 1, 90-95.

100. Starkova, K.G.; Bezruchenko, N.V.; Luchnikova, V.A.; Legostaeva, T.A. Features of the immune indicators at the adult population living in areas with contamination of drinking water by heavy metals. Russ. J. Immunol. 2015, 9, 320-321. (In Russian)

101. Maksimovich, N.; Menshikova, E.; Blinov, S. Some technogenic minerals of the Ural region. Mineral. Technog. 2000, 1, 62-67.

102. Sokol, E.; Maksimova, N. Nature, chemical and phase composition of energy ash from brown coals of the Chelyabinsk basin. Mineral. Technog. 2000, 1, 127-145.

103. Kopylov, I.; Naumov, V.; Spassky, B.; Maklashin, A. Geoecological assessment of mining and oil and gas bearing karst regions of the Middle Urals. Mod. Probl. Sci. Educ. 2014, 5, 678.

104. OAO "Gubakhinsky Coke". Available online: https://stroyservis.com/about/companies/detail/9 (accessed on 1 June 2020). (In Russian).

105. State Report "On the State and Protection of the Environment of the Perm Region in 2014". Available online: http://www.permecology.ru/\%d0\%b5\%d0\%b6\%d0\%b5\%d0\%b3\%d0\%be \%d0\%b4\%d0\%bd \%d1\%8b \%d0\%

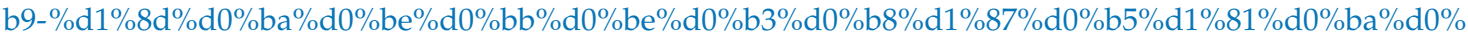
b8\%d0\%b9-\%d0\%b4\%d0\%be\%d0\%ba\%d0\%bb\%d0\%b0\%d0\%b4/\%d0\%b5\%d0\%b6\%d0\%b5\%d0\%b3\%d0\% be $\%$ d0\%b4\%d0\%bd\%d1\%8b\%d0\%b9-\%d1\%8d\%d0\%ba\%d0\%be\%d0\%bb\%d0\%be\%d0\%b3\%d0\%b8\%d1\% 87\%d0\%b5\%d1\%81\%d0\%ba\%d0\%b8\%d0\%b9-\%d0\%b4\%d0\%be\%d0\%ba\%d0\%bb\%d0\%b0\%d0\%b4-2013/ (accessed on 1 June 2020). (In Russian).

106. State Report "On the State and Protection of the Environment of the Perm Region in 2015". Available online: http://www.permecology.ru/\%d0\%b5\%d0\%b6\%d0\%b5\%d0\%b3\%d0\%be \%d0\%b4\%d0\%bd \%d1\%8b \%d0\% b9-\%d1\%8d\%d0\%ba\%d0\%be\%d0\%bb\%d0\%be\%d0\%b3\%d0\%b8\%d1\%87\%d0\%b5\%d1\%81\%d0\%ba\%d0\% b8\%d0\%b9-\%d0\%b4\%d0\%be\%d0\%ba\%d0\%bb\%d0\%b0\%d0\%b4/\%d0\%b5\%d0\%b6\%d0\%b5\%d0\%b3\%d0\% be $\%$ d0\%b4\%d0\%bd\%d1\%8b\%d0\%b9-\%d1\%8d\%d0\%ba\%d0\%be\%d0\%bb\%d0\%be\%d0\%b3\%d0\%b8\%d1\% 87\%d0\%b5\%d1\%81\%d0\%ba\%d0\%b8\%d0\%b9-\%d0\%b4\%d0\%be\%d0\%ba\%d0\%bb\%d0\%b0\%d0\%b4-2015/ (accessed on 1 June 2020). (In Russian).

107. State Report "On the State and Protection of the Environment of the Perm Region in 2016". Available online: http://www.permecology.ru/\%d0\%b5\%d0\%b6\%d0\%b5\%d0\%b3\%d0\%be \%d0\%b4\%d0\%bd\%d1\%8b\%d0\% b9-\%d1\%8d\%d0\%ba\%d0\%be\%d0\%bb\%d0\%be\%d0\%b3\%d0\%b8\%d1\%87\%d0\%b5\%d1\%81\%d0\%ba \%d0\% b8\%d0\%b9-\%d0\%b4\%d0\%be\%d0\%ba\%d0\%bb\%d0\%b0\%d0\%b4/\%d0\%b5\%d0\%b6\%d0\%b5\%d0\%b3\%d0\% be \%d0\%b4\%d0\%bd\%d1\%8b\%d0\%b9-\%d1\%8d\%d0\%ba\%d0\%be\%d0\%bb\%d0\%be\%d0\%b3\%d0\%b8\%d1\% 87\%d0\%b5\%d1\%81\%d0\%ba\%d0\%b8\%d0\%b9-\%d0\%b4\%d0\%be\%d0\%ba\%d0\%bb\%d0\%b0\%d0\%b4-2016/ (accessed on 1 June 2020). (In Russian).

108. State Report "On the State and protection of the Environment of the Perm Region in 2017". Available online: http://www.permecology.ru/\%d0\%b5\%d0\%b6\%d0\%b5\%d0\%b3\%d0\%be \%d0\%b4\%d0\%bd\%d1\%8b\%d0\% b9-\%d1\%8d\%d0\%ba\%d0\%be\%d0\%bb\%d0\%be\%d0\%b3\%d0\%b8\%d1\%87\%d0\%b5\%d1\%81\%d0\%ba\%d0\% b8\%d0\%b9-\%d0\%b4\%d0\%be\%d0\%ba\%d0\%bb\%d0\%b0\%d0\%b4/\%d0\%b5\%d0\%b6\%d0\%b5\%d0\%b3\%d0\% be \%d0\%b4\%d0\%bd\%d1\%8b\%d0\%b9-\%d1\%8d\%d0\%ba\%d0\%be\%d0\%bb\%d0\%be\%d0\%b3\%d0\%b8\%d1\% 87\%d0\%b5\%d1\%81\%d0\%ba\%d0\%b8\%d0\%b9-\%d0\%b4\%d0\%be\%d0\%ba\%d0\%bb\%d0\%b0\%d0\%b4-2017/ (accessed on 1 June 2020). (In Russian).

109. State Report "On the State and Protection of the Environment of the Perm Region in 2018". Available online: http://www.permecology.ru/\%d0\%b5\%d0\%b6\%d0\%b5\%d0\%b3\%d0\%be \%d0\%b4\%d0\%bd \%d1\% 8b\%d0\%b9-\%d1\%8d\%d0\%ba\%d0\%be\%d0\%bb\%d0\%be\%d0\%b3\%d0\%b8\%d1\%87\%d0\%b5\%d1\%81\%d0\% ba $\%$ d0\%b8\%d0\%b9-\%d0\%b4\%d0\%be\%d0\%ba\%d0\%bb\%d0\%b0\%d0\%b4-2018/ (accessed on 1 June 2020). (In Russian). 
110. State Report "On the State and Protection of the Environment of the Perm Region in 2019". Available online: http://www.permecology.ru/\%d0\%b5\%d0\%b6\%d0\%b5\%d0\%b3\%d0\%be \%d0\%b4\%d0\%bd\%d1\%8b\%d0\% b9-\%d1\%8d\%d0\%ba\%d0\%be \%d0\%bb\%d0\%be \%d0\%b3\%d0\%b8\%d1\%87\%d0\%b5\%d1\%81\%d0\%ba\%d0\% b8 \%d0\%b9-\%d0\%b4\%d0\%be\%d0\%ba\%d0\%bb\%d0\%b0\%d0\%b4/\%d0\%b5\%d0\%b6\%d0\%b5\%d0\%b3\%d0\% be $\%$ d0 $\%$ b4\%d0\%bd \%d1\%8b\%d0\%b9-\%d1\%8d\%d0\%ba\%d0\%be\%d0\%bb\%d0\%be\%d0\%b3\%d0\%b8\%d1\% 87\%d0\%b5\%d1\%81\%d0\%ba\%d0\%b8\%d0\%b9-\%d0\%b4\%d0\%be\%d0\%ba\%d0\%bb\%d0\%b0\%d0\%b4-2019/ (accessed on 1 June 2020). (In Russian).

111. Nifantov, B.F.; Potapov, V.P.; Anferov, B.A.; Kuznetsova, L.V. Coals of Kuzbass: Chemical Elements-Impurities and Technologies for Their Extraction during the Integrated Development of Deposits; Institute of Coal Siberian Branch of the Russian Academy of Sciences: Kemerovo, Russia, 2011; p. 310. (In Russian)

112. Skryabina, O.A. Mineralogical Composition of Soils and Parent Rocks: Textbook; Publishing House Perm State Agricultural Academy: Perm, Russia, 2010.

113. Korotaev, N.Y. Soils of the Perm Region; Perm Book Publishing House: Perm, Russia, 1962; p. 278. (In Russian)

114. Tartakovsky, A.M. Atlas of the Perm Territory; Perm State National Research University: Perm, Russia, 2012; p. 124. (In Russian)

115. Estimation of the Population of the Perm Territory as of 01.01.2019. Available online: https://permstat.gks.ru (accessed on 1 June 2020). (In Russian).

116. Urban Zoning Map of Gubakha. Available online: https://fgistp.economy.gov.ru/?show_document=truedoc_ type $=$ npauin $=57030101201911052$ (accessed on 1 June 2020). (In Russian)

117. Amendments to the General Plan of the Gubakhinsky Urban District of the Perm Region, 2019, Volume 1. Available online: http://gubakhaokrug.ru (accessed on 1 June 2020). (In Russian).

118. Gubakhinsky Urban District (Official Site). Available online: http://old.gubakhaokrug.ru/O-rajone/ (accessed on 1 June 2020). (In Russian).

119. Gubakha. Information. Available online: http://www.gubaha.com/Pages/p15 (accessed on 1 June 2020). (In Russian).

120. IUSS Working Group WRB. World Reference Base for Soil Resources 2014, Update 2015: International Soil Classification System for Naming Soils and Creating Legends for Soil Maps; World Soil Resources Report No. 106; Food and Agriculture Organization (FAO) of the United Nations: Rome, Italy, 2015; p. 203.

121. Weather Archive of Gubakha. Available online: https://world-weather.ru/archive/russia/gubakha/ (accessed on 1 June 2020). (In Russian).

122. Arinushkina, E.M. Handbook for Chemical Analysis of Soils; Chimiya Publishing House: Moscow, Russia, 1992; p. 425. (In Russian)

123. Kachinskiy, N.A. Soil Physics_-Part 1; Higher Education Publishing House (USSR): Moscow, Russia, 1965; p. 321. (In Russian)

124. Branch Standard OST 41-08-205-99. In Techniques of Quantitative Chemical Analysis; VIMS: Moscow, Russia, 1999; p. 96.

125. Zonn, S.V. Iron in Soils (Genetic and Geographic Aspects); Kovda, V.A., Ed.; Nauka: Moscow, Russia, 1982; p. 208. (In Russian)

126. Zonn, S.V.; Rukaka, A.N. Methods for the determination of non-silicate forms of iron in soils. Soil Sci. 1978, 2, 89-101. (In Russian)

127. Muller, G. Heavy-metals in sediment of the Rhine-changes since 1971. Umsch. Wiss. Tech. 1979, 79, 778-783.

128. Saet, I.E.; Revich, B.A.; Ianin, E.P.; Smirnova, R.S.; Basharkevich, I.L.; Onishchenko, T.L.; Pavlova, L.N.; Trefilova, N.I.; Achkasova, A.I.; Sarkisian, S.S. Geochemistry of the Environment; Nedra: Moscow, Russia, 1990; p. 333. (In Russian)

129. Alekseenko, V.A.; Alekseenko, A.V. Chemical Elements in Geochemical Systems. Clarks of Soils of Residential Landscapes; Publishing House of the Southern Federal University: Rostov-on-Don, Russia, 2013; p. 388. (In Russian)

130. Tomlinson, D.; Wilson, J.; Harris, C.; Jeffrey, D. Problems in the assessment of heavy-metal levels in estuaries and the formation of a pollution index. Helgol. Meeresunters 1980, 33, 566-575. [CrossRef]

131. Schwertmann, U. Occurrence and formation of iron oxides in various pedoenvironments. In Iron in Soils and Clay Minerals; Springer: Berlin/Heidelberg, Germany, 1988; pp. 267-308.

132. Vodyanitskii, Y.N. Chemistry and Mineralogy of Soil Iron; Soil. in-t Named after V.V.; Dokuchaev: Moscow, Russia, 2003; p. 236. (In Russian) 
133. Dmitriev, E.A. Mathematical Statistics in Soil Science; URSS: Moscow, Russia, 2008; p. 326. (In Russian)

134. Żbik, M. Morphology of the outermost shells of the Tunguska black magnetic spherules. J. Geophys. Res. Solid Earth 1984, 89, B605-B611. [CrossRef]

135. Szöőrr, G.; Elekes, Z.; Rózsa, P.; Uzonyi, I.; Simulák, J.; Kiss, Á. Magnetic spherules: Cosmic dust or markers of a meteoritic impact? Nucl. Instrum. Methods Phys. Res. Sect. B Beam Interact. Mater. Atoms 2001, 181, 557-562. [CrossRef]

136. Zagurskii, A.M.; Ivanov, A.V.; Shoba, S.A. Submicromorphology of soil magnetic fractions. Eurasian Soil Sci. 2009, 42, 1044-1052. [CrossRef]

137. Nyström, J.O.; Henríquez, F.; Naranjo, J.A.; Naslund, H.R. Magnetite spherules in pyroclastic iron ore at El Laco, Chile. Am. Mineral. 2016, 101, 587-595. [CrossRef]

138. Blaha, U.; Appel, E.; Stanjek, H. Determination of anthropogenic boundary depth in industrially polluted soil and semi-quantification of heavy metal loads using magnetic susceptibility. Environ. Pollut. 2008, 156, 278-289. [CrossRef]

139. Razinsky, M.V.; Gette, E.A.; Vasiliev, A.A. The total content of heavy metals in different magnetic soils of the city of Gubakha. In Proceedings of the All-Russian Scientific-Practical Conference YOUTH SCIENCE 2014: Technologies, Innovations; Prokrost: Perm, Russia, 2014; Volume 1, pp. 316-319. (In Russian)

140. Samofalova, I.A.; Luzyanina, O.A. Mountain Soils of the Middle Urals (on the Example of the Basegi); Prokrost: Perm, Russia, 2014; p. 154. (In Russian)

141. Lu, S.; Chen, Y.; Shan, H.; Bai, S. Mineralogy and heavy metal leachability of magnetic fractions separated from some Chinese coal fly ashes. J. Hazard. Mater. 2009, 169, 246-255. [CrossRef]

142. Hunt, A.; Jones, J.; Oldfield, F. Magnetic measurements and heavy metals in atmospheric particulates of anthropogenic origin. Sci. Total Environ. 1984, 33, 129-139. [CrossRef]

143. Interstate Standard GOST 17.4.1.02-83. Nature Protection. Soils. Classification of Chemicals for Pollution Control; Standardinform: Moscow, Russia, 2008; p. 3. (In Russian)

144. Vodyanitskii, Y.N. Iron Compounds and Their Role in Soil Protection; Soil. in-t Named after V.V.; Dokuchaev: Moscow, Russia, 2003; p. 133. (In Russian)

Publisher's Note: MDPI stays neutral with regard to jurisdictional claims in published maps and institutional affiliations.

(C) 2020 by the authors. Licensee MDPI, Basel, Switzerland. This article is an open access article distributed under the terms and conditions of the Creative Commons Attribution (CC BY) license (http://creativecommons.org/licenses/by/4.0/). 